\title{
Predominance of methanogens over methanotrophs in rewetted fens characterized by high methane emissions
}

\author{
Xi Wen ${ }^{1,14}$, Viktoria Unger ${ }^{2}$, Gerald Jurasinski ${ }^{2}$, Franziska Koebsch ${ }^{2}$, Fabian Horn ${ }^{1}$, Gregor Rehder ${ }^{3}$, \\ Torsten Sachs ${ }^{4}$, Dominik Zak ${ }^{5,6}$, Gunnar Lischeid ${ }^{7,8}$, Klaus-Holger Knorr ${ }^{9}$, Michael E. Böttcher ${ }^{10}$, \\ Matthias Winkel $^{1,11}$, Paul L. E. Bodelier ${ }^{12}$, and Susanne Liebner ${ }^{1,13}$ \\ ${ }^{1}$ Section 5.3 Geomicrobiology, GFZ German Research Centre for Geosciences, Helmholtz Centre Potsdam, \\ Telegrafenberg, 14473 Potsdam, Germany \\ ${ }^{2}$ Landscape Ecology and Site Evaluation, Faculty for Agricultural and Environmental Sciences, \\ Rostock University, 18059 Rostock, Germany \\ ${ }^{3}$ Department of Marine Chemistry, Leibniz Institute for Baltic Sea Research, 18119 Warnemünde, Germany \\ ${ }^{4}$ Section 1.4 Remote Sensing, GFZ German Research Centre for Geosciences, Helmholtz Centre Potsdam, \\ Telegrafenberg, 14473 Potsdam, Germany \\ ${ }^{5}$ Department of Bioscience, Aarhus University, 8600 Silkeborg, Denmark \\ ${ }^{6}$ Department of Chemical Analytics and Biogeochemistry, Leibniz Institute of Freshwater Ecology and Inland Fisheries, \\ 12587 Berlin, Germany \\ ${ }^{7}$ Institute of Landscape Hydrology, Leibniz Center for Agricultural Landscape Research, 15374 Münchberg, Germany \\ ${ }^{8}$ Institute of Earth and Environmental Science, University of Potsdam, 14476 Potsdam, Germany \\ ${ }^{9}$ Institute of Landscape Ecology, University of Münster, 48149 Münster, Germany \\ ${ }^{10}$ Geochemistry and Stable Isotope Biogeochemistry, Leibniz Institute for Baltic Sea Research, \\ 18119 Warnemünde, Germany \\ ${ }^{11}$ Water and Environmental Research Center, Institute of Northern Engineering, University of Alaska Fairbanks, \\ 306 Tanana Loop, Fairbanks, AK 99775, USA \\ ${ }^{12}$ Department of Microbial Ecology, Netherlands Institute of Ecology (NIOO-KNAW), Droevendaalsesteeg 10, \\ 6708PB Wageningen, the Netherlands \\ ${ }^{13}$ University of Potsdam, Institute of Biochemistry and Biology, 14469 Potsdam, Germany \\ ${ }^{14}$ College of Electrical Engineering, Northwest Minzu University, Lanzhou, 730070, China
}

Correspondence: Viktoria Unger (viktoria.unger@uni-rostock.de)

and Franziska Koebsch (franziska.koebsch@uni-rostock.de)

Received: 11 April 2018 - Discussion started: 26 April 2018

Revised: 4 October 2018 - Accepted: 8 October 2018 - Published: 6 November 2018

\begin{abstract}
The rewetting of drained peatlands alters peat geochemistry and often leads to sustained elevated methane emission. Although this methane is produced entirely by microbial activity, the distribution and abundance of methanecycling microbes in rewetted peatlands, especially in fens, is rarely described. In this study, we compare the community composition and abundance of methane-cycling microbes in relation to peat porewater geochemistry in two rewetted fens in northeastern Germany, a coastal brackish fen and a freshwater riparian fen, with known high methane
\end{abstract}

fluxes. We utilized 16S rRNA high-throughput sequencing and quantitative polymerase chain reaction (qPCR) on $16 \mathrm{~S}$ rRNA, $m c r A$, and $p m o A$ genes to determine microbial community composition and the abundance of total bacteria, methanogens, and methanotrophs. Electrical conductivity (EC) was more than 3 times higher in the coastal fen than in the riparian fen, averaging 5.3 and $1.5 \mathrm{mS} \mathrm{cm}^{-1}$, respectively. Porewater concentrations of terminal electron acceptors (TEAs) varied within and among the fens. This was also reflected in similarly high intra- and inter-site varia- 
tions of microbial community composition. Despite these differences in environmental conditions and electron acceptor availability, we found a low abundance of methanotrophs and a high abundance of methanogens, represented in particular by Methanosaetaceae, in both fens. This suggests that rapid (re)establishment of methanogens and slow (re)establishment of methanotrophs contributes to prolonged increased methane emissions following rewetting.

\section{Introduction}

Rewetting is a technique commonly employed to restore ecological and biogeochemical functioning of drained fens. However, while rewetting may reduce carbon dioxide $\left(\mathrm{CO}_{2}\right)$ emissions (Wilson et al., 2016), it often increases methane $\left(\mathrm{CH}_{4}\right)$ emissions in peatlands that remain inundated following rewetting. On a 100-year timescale, $\mathrm{CH}_{4}$ has a global warming potential 28 times stronger than $\mathrm{CO}_{2}$ (Myhre et al., 2013), and the factors that contribute to the magnitude and duration of increased emissions are still uncertain (Joosten et al., 2015; Abdalla et al., 2016). Thus, elucidating the dynamics of post-rewetting $\mathrm{CH}_{4}$ exchange is of strong interest for both modeling studies and peatland management projects (Abdalla et al., 2016). Although a recent increase in rewetting projects in Germany and other European countries has prompted a number of studies of methane cycling in rewetted peatlands (e.g., Jerman et al., 2009; Hahn-Schöfl et al., 2011; Urbanová et al., 2013; Hahn et al., 2015; Vanselow-Algan et al., 2015; Zak et al., 2015; Emsens et al., 2016; Putkinen et al., 2018), the post-rewetting distribution and abundance of methane-cycling microbes in rewetted fens has seldom been examined (but see Juottonen et al., 2012; Urbanová et al., 2013; Putkinen et al., 2018).

Peat $\mathrm{CH}_{4}$ production and release is governed by a complex array of interrelated factors including climate, water level, plant community, nutrient status, site geochemistry, and the activity of microbes (i.e., bacteria and archaea) that use organic carbon as an energy source (Segers, 1998; Abdalla et al., 2016). To date, the vast majority of studies in rewetted fens have focused on quantifying $\mathrm{CH}_{4}$ emission rates in association with environmental variables such as water level, plant community, and aspects of site geochemistry (Abdalla et al., 2016). Site geochemistry indeed plays an important role for methanogenic communities, as methanogenesis is suppressed in the presence of thermodynamically more favorable terminal electron acceptors (TEAs, Blodau, 2011). Due to a smaller pool of more favorable electron acceptors and high availability of organic carbon substrates, organicrich soils such as peat rapidly establish methanogenic conditions post-rewetting (Segers, 1998; Keller and Bridgham, 2007; Knorr and Blodau, 2009). Despite their decisive role as producers (i.e., methanogens) and consumers (i.e., methanotrophs) of $\mathrm{CH}_{4}$ (Conrad, 1996), only a few studies have combined a characterization of the $\mathrm{CH}_{4}$-cycling microbial community, site geochemistry, and observed trends in $\mathrm{CH}_{4}$ production. Existing studies have been conducted in oligotrophic and mesotrophic boreal fens (e.g., Juottonen et al., 2005, 2012; Yrjälä et al., 2011), alpine fens (e.g., Liebner et al., 2012; Urbanová et al., 2013; Cheema et al., 2015; Franchini et al., 2015), subarctic fens (Liebner et al., 2015), and incubation experiments (e.g., Jerman et al., 2009; Knorr and Blodau, 2009; Urbanová et al., 2011; Emsens et al., 2016). Several studies on $\mathrm{CH}_{4}$-cycling microbial communities have been conducted in minerotrophic temperate fens (e.g., Cadillo-Quiroz et al., 2008; Liu et al., 2011; Sun et al., 2012; Zhou et al., 2017), but these sites were not subject to drainage or rewetting. Direct comparisons of in situ abundances of methanogens and methanotrophs in drained versus rewetted fens are scarce (Juottonen et al., 2012; Putkinen et al., 2018), and the studied sites, so far, are nutrient-poor fens with acidic conditions.

While studies of nutrient-poor and mesotrophic boreal fens have documented post-rewetting $\mathrm{CH}_{4}$ emissions comparable to or lower than at pristine sites (Komulainen et al., 1998; Tuittila et al., 2000; Juottonen et al., 2012), studies of temperate nutrient-rich fens have reported post-flooding $\mathrm{CH}_{4}$ emissions dramatically exceeding emissions in pristine fens (e.g., Augustin and Chojnicki, 2008; Hahn et al., 2015). These high emissions typically occur together with a significant dieback in vegetation, a mobilization of nutrients and electron acceptors in the upper peat layer, and increased availability of dissolved organic matter (Zak and Gelbrecht, 2007; Hahn-Schöfl et al., 2011; Hahn et al., 2015; Jurasinski et al., 2016). High $\mathrm{CH}_{4}$ fluxes may continue for decades following rewetting, even in bogs (Vanselow-Algan et al., 2015). Hence, there is an urgent need to characterize $\mathrm{CH}_{4}$-cycling microbial communities and geochemical conditions in rewetted minerotrophic fens. In this study, we therefore examined microbial community composition and abundance in relation to post-flooding geochemical conditions in two rewetted fens in northeastern Germany. In both fens, $\mathrm{CH}_{4}$ emissions increased dramatically after rewetting, to over $200 \mathrm{~g} \mathrm{C} \mathrm{m}^{-2} \mathrm{a}^{-1}$ (Augustin and Chojnicki, 2008; HahnSchöfl et al., 2011; Hahn et al., 2015; Jurasinski et al., 2016). Average annual $\mathrm{CH}_{4}$ emissions have decreased in both fens since the initial peak (Franz et al., 2016; Jurasinski et al., 2016). Nevertheless, fluxes remained higher than under preflooding conditions (ibid.) and higher than in pristine fens (Urbanová et al., 2013; Minke et al., 2016). In the Hütelmoor in 2012, average $\mathrm{CH}_{4}$ emissions during the growing season were $40 \mathrm{~g} \mathrm{~m}^{-2}$ (Koebsch et al., 2015). In Zarnekow, average $\mathrm{CH}_{4}$ emissions were $40 \mathrm{~g} \mathrm{~m}^{-2}$ for the year 2013 (Franz et al., 2016). In comparison, a recent review paper (Abdalla et al., 2016) estimated an average flux of $12 \pm 21 \mathrm{~g} \mathrm{C} \mathrm{m}^{-2} \mathrm{a}^{-1}$ for pristine peatlands.

We expected patterns in microbial community composition would reflect the geochemical conditions of the two sites and hypothesized a high abundance of methanogens relative 

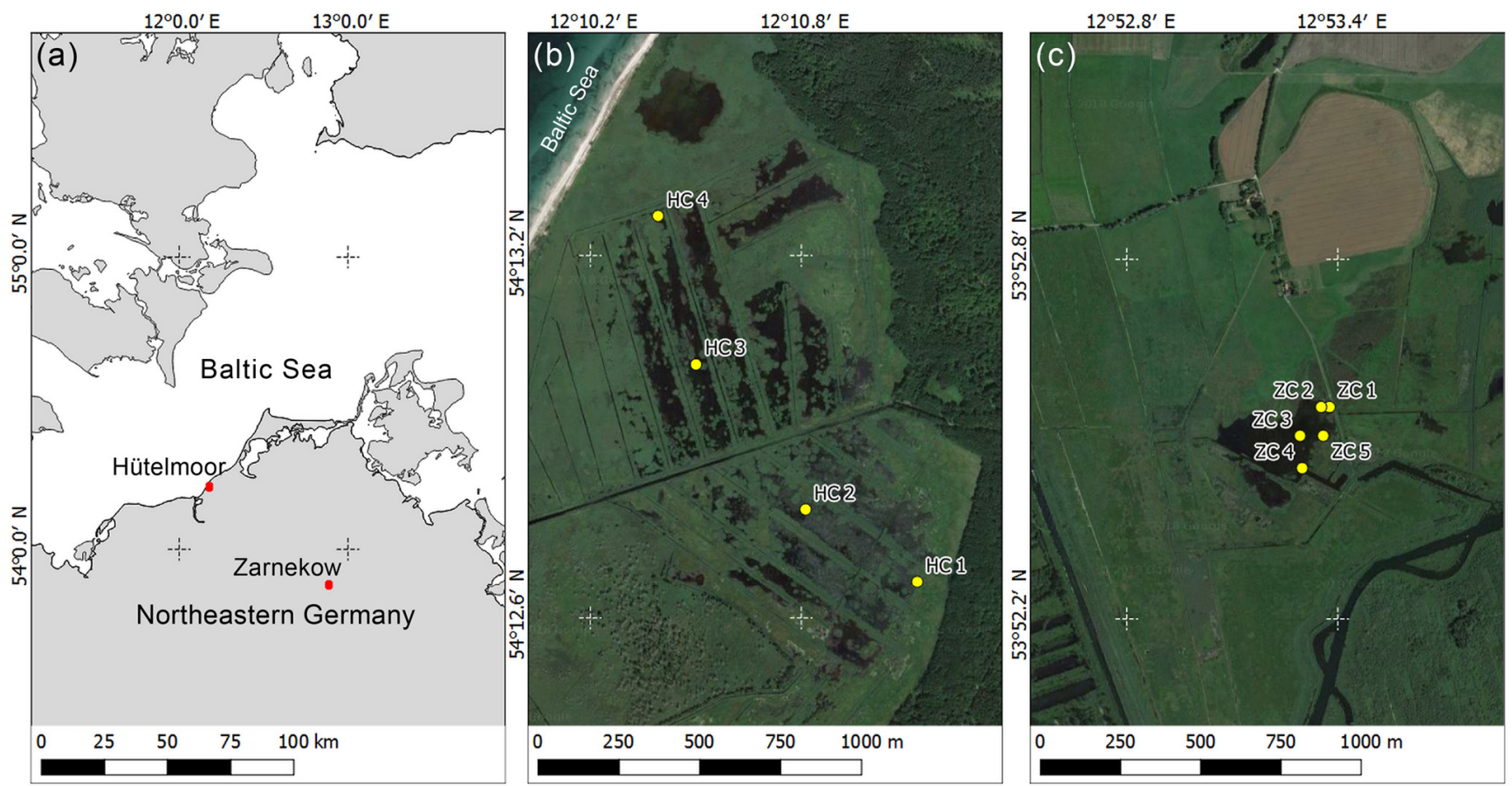

Figure 1. Location of study sites in northeastern Germany (a) and sampling locations within sites (b) Hütelmoor and (c) Zarnekow. Maps (b) and (c) are drawn to the same scale. Image source: (a) QGIS; (b) and (c) Google Earth via QGIS OpenLayers Plugin. Imagery date: 9 August 2015.

to methanotrophs in both fens. We also expected acetoclastic methanogens, which typically thrive in nutrient-rich fens (Kelly et al., 1992; Galand et al., 2005), to dominate the methanogenic community in both fens.

\section{Methods}

\subsection{Study sites}

The nature reserve Heiligensee and Hütelmoor ("Hütelmoor" in the following; approx. 540 ha; $54^{\circ} 12^{\prime} 36.66^{\prime \prime} \mathrm{N}$, $12^{\circ} 10^{\prime} 34.28^{\prime \prime} \mathrm{E}$ ) is a coastal, mainly minerotrophic fen complex in Mecklenburg-Vorpommern (NE Germany) that is separated from the Baltic Sea by a narrow $(\sim 100 \mathrm{~m}$ and less $)$ dune dike (Fig. 1a and b). The climate is temperate in the transition zone between maritime and continental, with an average annual temperature of $9.1^{\circ} \mathrm{C}$ and an average annual precipitation of $645 \mathrm{~mm}$ (data derived from the grid product of the German Weather Service, reference climate period 1981-2010). Episodic flooding from storm events delivers sediment and brackish water to the site (Weisner and Schernewski, 2013). The vegetation is a mixture of salt-tolerant macrophytes, with dominant to semi-dominant stands of Phragmites australis, Bolboschoenus maritimus, Carex acutiformis, and Schoenoplectus tabernaemontani. The dominating plants are interspersed with open water bodies that are colonized by Ceratophyllum demersum in summer (Koch et al., 2017). Intense draining and land amelioration practices began in the 1970s, which lowered the water level to $1.6 \mathrm{~m}$ below ground surface and caused aerobic decomposition and concomitant degradation of the peat (Voigtländer et al., 1996). The upper peat layer varies in depth between 0.6 and $3 \mathrm{~m}$ and is highly degraded, reaching up to H10 on the von Post humification scale (Hahn et al., 2015). Active draining ended in 1992, but dry conditions during summertime kept the water table well below ground surface (SchönfeldBockholt et al., 2008; Koebsch et al., 2013) until concerns of prolonged aerobic peat decomposition prompted the installation of a weir in 2009 at the outflow of the catchment (Weisner and Schernewski, 2013). After installation of the weir, the site has been fully flooded year-round with an average water level of $0.6 \mathrm{~m}$ above the peat surface, and annual average $\mathrm{CH}_{4}$ flux increased $\sim$ 186-fold from 0.0014 \pm 0.0006 to $0.26 \pm 0.06 \mathrm{~kg} \mathrm{CH}_{4} \mathrm{~m}^{-2} \mathrm{a}^{-1}$ (Hahn et al., 2015).

The study site polder Zarnekow ("Zarnekow" in the following; approx. $500 \mathrm{ha} ; 53^{\circ} 52^{\prime} 31.10^{\prime \prime} \mathrm{N}, 12^{\circ} 53^{\prime} 19.60^{\prime \prime} \mathrm{E}$ ) is situated in the valley of the river Peene in MecklenburgVorpommern (NE Germany, Fig. 1a and c). The climate is slightly more continental compared to the Hütelmoor, with a mean annual precipitation of $544 \mathrm{~mm}$ and a mean annual temperature of $8.7^{\circ} \mathrm{C}$ (German Weather Service, meteorological station Teterow, $24 \mathrm{~km}$ southwest of the study site; reference period 1981-2010). The fen can be classified as a river valley mire system consisting of spring mires, wider 
percolation mires, and flood mires along the river Peene. Drainage and low-intensity agricultural use began in the 18th century when land use changed to pastures and grassland. This was intensified by active pumping in the mid-1970s. Due to land subsidence of several decimeters, after rewetting (October 2004) the water table depth increased to $0.1-0.5 \mathrm{~m}$ above the peat surface. The upper horizon is highly decomposed $(0-0.3 \mathrm{~m})$, followed by moderately decomposed peat to a depth of $1 \mathrm{~m}$ and a deep layer of slightly decomposed peat up to a maximum depth of $10 \mathrm{~m}$. The open water bodies are densely colonized by Ceratophyllum spp. and Typha latifolia is the dominant emergent macrophyte (Steffenhagen et al., 2012). Following flooding, $\mathrm{CH}_{4}$ flux rates increased to $\sim 0.21 \mathrm{~kg} \mathrm{~m}^{-2} \mathrm{a}^{-1}$ (Augustin and Chojnicki, 2008). No prerewetting $\mathrm{CH}_{4}$ flux data were available for the Zarnekow site, but published $\mathrm{CH}_{4}$ flux rates of representative drained fens from the same region have been shown to be negligible, and many were $\mathrm{CH}_{4}$ sinks (Augustin et al., 1998).

\subsection{Collection and analysis of peat cores and porewater samples}

Peat and porewater samples were collected at four different locations $(n=4)$ in Hütelmoor (October 2014) and at five locations $(n=5)$ in Zarnekow (July 2015) and spanned a distance of 1200 and $250 \mathrm{~m}$, respectively, to cover the whole lateral extension at each site (Fig. 1b and c). Sampling depths in the Hütelmoor were $0-5,5-10,10-20,20-30,30-40$, and $40-50 \mathrm{~cm}$ below the peat surface, except for core numbers 1 and 4 where samples could only be obtained up to a depth of $10-20$ and $30-40 \mathrm{~cm}$, respectively. Sampling depths in Zarnekow were $0-5,25-30$, and $50-55 \mathrm{~cm}$ below the peat surface. Previous work at Zarnekow has revealed little variation in peat properties with depth (e.g., Zak and Gelbrecht, 2007); hence, a lower depth resolution in Zarnekow cores (ZCs) was chosen for this study. Peat cores were collected with a Perspex liner (ID: $60 \mathrm{~mm}$, Hütelmoor) and a peat auger (Zarnekow). In order to minimize oxygen contamination, the outer layer of the peat core was omitted. Subsamples for molecular analysis were immediately packed in $15 \mathrm{~mL}$ sterile Falcon tubes and stored at $-80^{\circ} \mathrm{C}$ until further processing.

Pore waters in the Hütelmoor were collected with a stainless-steel push-point sampler attached to a plastic syringe to recover the samples from $10 \mathrm{~cm}$ depth intervals. Samples were immediately filtered with $0.45 \mu \mathrm{m}$ membrane, sterile, disposable syringe filters. Pore waters in Zarnekow were sampled with permanently installed dialysis samplers consisting of slotted polypropylene (PP) pipes (length: $636 \mathrm{~mm}$, ID: $34 \mathrm{~mm}$ ) surrounded with $0.22 \mu \mathrm{m}$ polyethersulfone membrane. The PP pipes were fixed at distinct peat depths (surface level, 20 and $40 \mathrm{~cm}$ depth) and connected with PP tubes $(4 \times 6 \mathrm{~mm} \mathrm{ID} \times \mathrm{AD})$. Water samples were drawn out from the dialysis sampler pipes with a syringe through the PP tube. Due to practical restrictions in acces- sibility and sampling, permanent dialysis samplers could not be installed at the desired locations in the Hütelmoor, resulting in the different sampling techniques described above.

At both sites, electrical conductivity (EC), dissolved oxygen (DO), and $\mathrm{pH}$ were measured immediately after sampling (Sentix $41 \mathrm{pH}$ probe and a TetraCon 325 conductivity measuring cell attached to a WTW multi 340i handheld; WTW, Weilheim). In this paper, EC is presented and was not converted to salinity (i.e., psu), as a conversion would be imprecise for brackish waters. A simplified equation for conversion can be found in Schemel (2001). Headspace $\mathrm{CH}_{4}$ concentrations of porewater samples were measured with an Agilent 7890A gas chromatograph (Agilent Technologies, Germany) equipped with a flame ionization detector and a Carboxen PLOT Capillary Column or HP-Plot Q (Porapak-Q) column. The measured headspace $\mathrm{CH}_{4}$ concentration was then converted into a dissolved $\mathrm{CH}_{4}$ concentration using the temperature-corrected solubility coefficient (Wilhelm et al., 1977). Isotopic composition of dissolved $\mathrm{CH}_{4}$ for Hütelmoor was analyzed using the gas-chromatography-combustion technique (GC-C) and the gas-chromatography-high-temperature-conversion technique (GC-HTC). The gas was directly injected in a gas chromatograph (Agilent $7890 \mathrm{~A}$ ), $\mathrm{CH}_{4}$ was quantitatively converted to $\mathrm{CO}_{2}$, and the $\delta^{13} \mathrm{C}$ values were then measured with the isotope ratio mass spectrometer MAT-253 (Thermo Finnigan, Germany). The $\delta^{13} \mathrm{C}$ of dissolved $\mathrm{CH}_{4}$ in Zarnekow was analyzed using a laser-based isotope analyzer equipped with a small sample isotope module for analyses of discrete gas samples (cavity ring-down spectroscopy, CRDS; Picarro G2201-I, Santa Clara, CA, USA). Calibration was carried out before, during, and after analyses using certified standards of known isotopic composition (obtained from Isometric Instruments, Victoria, BC, Canada; and from Westfalen AG, Münster, Germany). Reproducibility of results was typically $\pm 1 \%$. In the presence of high concentrations of hydrogen sulfide interfering with laser-based isotope analysis, samples were treated with iron(III) sulfate to oxidize and/or precipitate sulfide. For both sites, sulfate and nitrate concentrations were analyzed by ion chromatography (IC, Thermo Fisher Scientific Dionex) using an IonPac AS-9-HC 4 column, partly after dilution of the sample. Dissolved metal concentrations were analyzed by inductively coupled plasma optical emission spectrometry (ICP-OES, iCAP 6300 DUO, Thermo Fisher Scientific). Accuracy and precision were routinely checked with a certified CASS standard as previously described (Kowalski et al., 2012).

For the incubation experiments, peat cores were collected from Zarnekow in March 2012 using a modified Kajak Corer with a plexiglass tube. The intact cores were placed in a cool box and immediately transported to the Leibniz Institute of Freshwater Ecology and Inland Fisheries in Berlin, where they were sectioned into a total of 12 samples. Fresh, surficial organic sediment $(0-10 \mathrm{~cm}$ depth, 6 individual samples) was separated from the bulk peat $(10-20 \mathrm{~cm}$ depth, 6 indi- 
vidual samples) and the samples were placed in $60 \mathrm{~mL}$ plastic cups. The cups were filled completely and closed with air-tight caps to minimize oxygen contamination. The samples were then express-shipped $(<24 \mathrm{~h})$ to the lab at the Netherlands Institute of Ecology for immediate processing and analysis. For $\mathrm{CH}_{4}$ production incubations, $5 \mathrm{~g}$ of material and $10 \mathrm{~mL}$ of nitrogen $\left(\mathrm{N}_{2}\right)$-flushed MilliQ water were weighed into three $(n=3) 150 \mathrm{~mL}$ flasks for both surficial organic sediment and bulk peat. The flasks were capped with rubber stoppers, flushed with $\mathrm{N}_{2}$ for approximately $1 \mathrm{~h}$, and then incubated stationarily at $20^{\circ} \mathrm{C}$ in the dark. For $\mathrm{CH}_{4}$ oxidation incubations, $5 \mathrm{~g}$ of fresh material and $10 \mathrm{~mL}$ of MilliQ water were weighed into three $150 \mathrm{~mL}$ flasks for both surficial organic sediment and bulk peat. The flasks were capped with rubber stoppers and $1.4 \mathrm{~mL}$ of pure $\mathrm{CH}_{4}$ was added to obtain a headspace $\mathrm{CH}_{4}$ concentration of approximately $10000 \mathrm{ppm}$. Incubations were performed in the dark at $20^{\circ} \mathrm{C}$ on a gyratory shaker $(120 \mathrm{rpm})$. For all incubations, headspace $\mathrm{CH}_{4}$ concentration was determined using a gas chromatograph equipped with a flame ionization detector on days $1,3,5$, and 8 of the incubation. Potential $\mathrm{CH}_{4}$ production and oxidation rates were determined by linear regression of $\mathrm{CH}_{4}$ concentration over all sampling times.

\subsection{Gene amplification and phylogenetic analysis}

Genomic DNA was extracted from $0.2-0.3 \mathrm{~g}$ of duplicates of peat soil per sample using an EurX GeneMATRIX soil DNA Purification Kit (Roboklon, Berlin, Germany). DNA concentrations were quantified with a Nanophotometer P360 (Implen GmbH, Munich, Germany) and Qubit 2.0 Fluorometer (Thermo Fisher Scientific, Darmstadt, Germany). Polymerase chain reaction (PCR) amplification of bacterial and archaeal 16S rRNA genes was performed using the primer combination of S-D-Bact-0341-b-S-17/S-DBact-0785-a-A-21 (Herlemann et al., 2011) and S-D-Arch0349-a-S-17/S-D-Arch-0786-a-A-20 (Takai and Horikoshi, 2000), respectively, with barcodes contained in the $5^{\prime}$ end. The PCR mix contained $1 \times$ PCR buffer (Tris $\cdot \mathrm{Cl}, \mathrm{KCl}$, $\left(\mathrm{NH}_{4}\right)_{2} \mathrm{SO}_{4}, 15 \mathrm{mM} \mathrm{MgCl}_{2} ; \mathrm{pH}$ 8.7) (QIAGEN, Hilden, Germany), $0.5 \mu \mathrm{M}$ of each primer (Biomers, Ulm, Germany), $0.2 \mathrm{mM}$ of each deoxynucleoside (Thermo Fisher Scien-

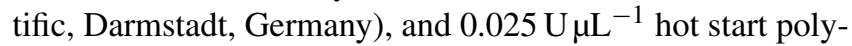
merase (QIAGEN, Hilden, Germany). PCR samples were kept at $95^{\circ} \mathrm{C}$ for 5 min to denature the DNA, with amplification proceeding for 40 cycles at $95^{\circ} \mathrm{C}$ for $1 \mathrm{~min}, 56^{\circ} \mathrm{C}$ for $45 \mathrm{~s}$, and $72^{\circ} \mathrm{C}$ for $90 \mathrm{~s}$; a final extension of $10 \mathrm{~min}$ at $72^{\circ} \mathrm{C}$ was added to ensure complete amplification. PCR products were purified with a Hi Yield Gel/PCR DNA fragment extraction kit (Süd-Laborbedarf, Gauting, Germany). To reduce amplification bias, PCR products of three individual runs per sample were combined. PCR products of different samples were pooled in equimolar concentrations and compressed to a final volume of $10 \mu \mathrm{L}$ with a concentration of $200 \mathrm{ng} \mu \mathrm{L}^{-1}$ in a vacuum centrifuge Concentrator Plus (Eppendorf, Hamburg, Germany).

Illumina sequencing was performed by GATC Biotech AG using $300 \mathrm{bp}$ paired-end mode and a $20 \%$ PhiX Control v3 library to counteract the effects of low-diversity sequence libraries. Raw data were demultiplexed using our own script based on CutAdapt (Martin, 2011). Ambiguous nucleotides at sequence ends were trimmed and a $10 \%$ mismatch was allowed for primer identification, whereas barcode sequences needed to be present without any mismatches and with a minimum Phred score of $Q_{25}$ for each nucleotide. After sorting, overlapping paired-end reads were merged using PEAR ( $Q_{25}$, p. 0.0001, v20) (Zhang et al., 2014). The orientation of the merged sequences was standardized according to the barcode information obtained from demultiplexing. Low-quality reads were removed using Trimmomatic (SE, LEADING $Q_{25}$, TRAILING $Q_{25}$, SLIDINGWINDOW 5 : 25; MINLEN 200) (Bolger et al., 2014). Chimeric sequences were removed using USEARCH 6.1 and the QIIME script identify_chimeric_seqs.py (Caporaso et al., 2010). Preprocessed sequences were taxonomically assigned to operational taxonomic units (OTUs) at a nucleotide sequence identity of $97 \%$ using QIIME's pick_open_reference_otus.py script and the GreenGenes database 13.05 (McDonald et al., 2012) as reference. The taxonomic assignment of representative sequences was further checked for correct taxonomical classification by phylogenetic tree calculations in the ARB environment referenced against the SILVA database version 119 (Quast et al., 2013). The resulting OTU table was filtered for singletons, for OTUs assigned to chloroplasts or mitochondria, and for low-abundance OTUs (below $0.2 \%$ within each sample). Archaeal and bacterial samples were processed separately while only OTUs that were assigned to the respective domain were considered for further analysis. For archaea, a total of 6844177 valid sequences were obtained, ranging from 60496 to 398660 in individual samples. These sequences were classified into 402 OTUs. For bacteria, a total of 2586148 valid sequences were obtained, ranging from 22826 to 164916 in individual samples. These sequences were classified into 843 OTUs. The OTU tables were then collapsed at a higher taxonomic level to generate the bubble plots. The $16 \mathrm{~S}$ rRNA gene sequence data have been deposited at NCBI under the BioProject PRJNA356778. The Hütelmoor sequence read archive accession numbers are SRR5118134SRR5118155 for bacterial and SRR5119428-SRR5119449 for archaeal sequences. The Zarnekow accession numbers are SRR6854018-SRR6854033 and SRR6854205SRR6854220 for bacterial and archaeal sequences, respectively.

\section{4 qPCR analysis}

Quantitative polymerase chain reaction (qPCR) for the determination of methanotrophic and methanogenic functional 
(a)
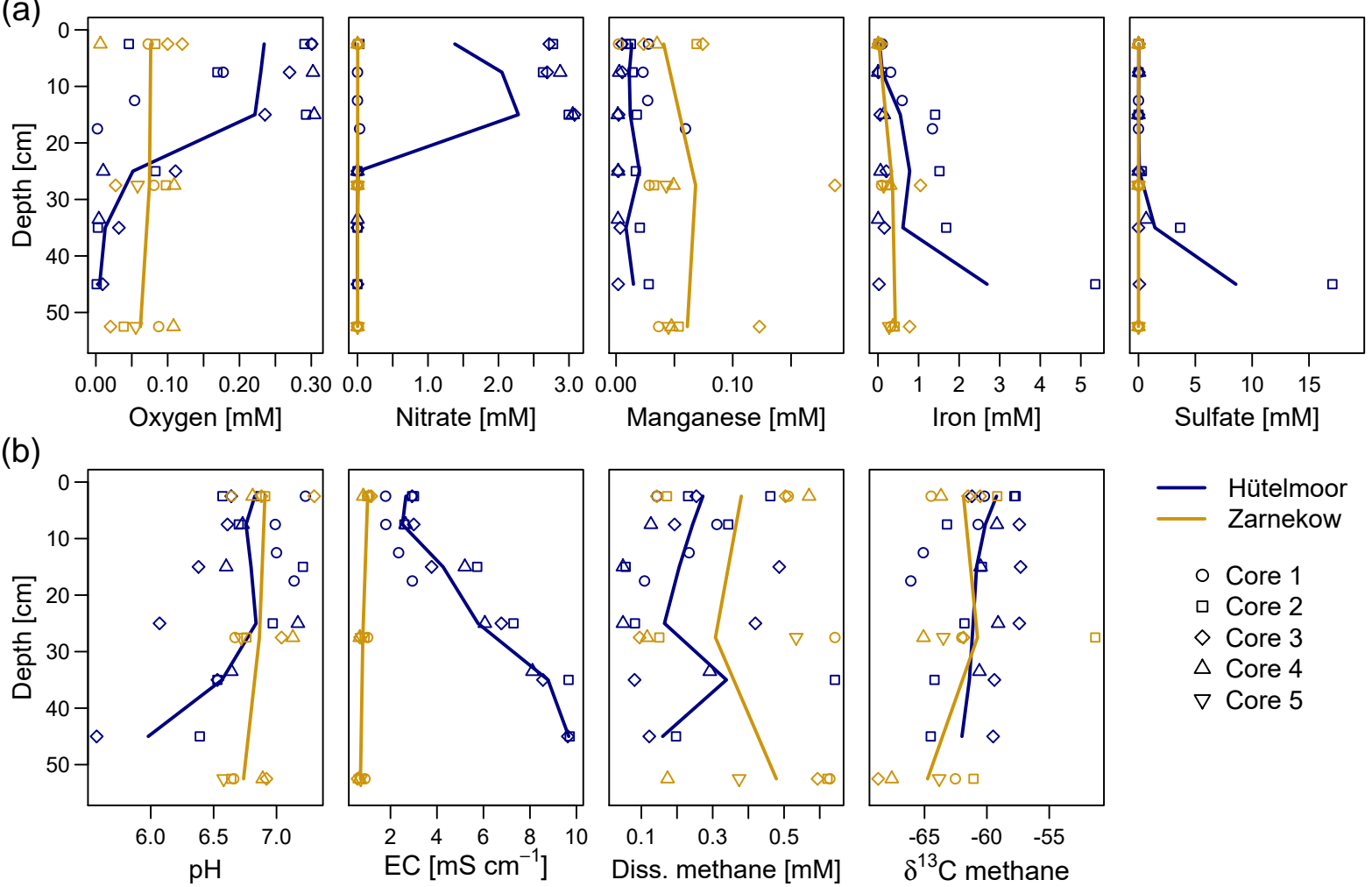

Figure 2. Depth profiles of oxygen, nitrate, total iron, manganese, and sulfate (a), and profiles of pH, EC, dissolved methane, and the isotopic signature of methane-bound carbon (b) in both study sites. Solid lines connect the respective means of individual wetlands $(n=4$ for Hütelmoor and $n=5$ for Zarnekow).

gene copy numbers and overall bacterial 16S rRNA gene copy numbers was performed via SYBR Green assays on a Bio-Rad CFX instrument (Bio-Rad, Munich, Germany) with slight modifications according to Liebner et al. (2015). The functional methanotrophic $p m o A$ gene was amplified with the primer combination A189F/Mb661 (Kolb et al., 2003) suitable for detecting all known aerobic methanotrophic Proteobacteria. Annealing was done at $55^{\circ} \mathrm{C}$ after a seven-cycle-step touchdown starting at $62{ }^{\circ} \mathrm{C}$. The functional methanogenic $m c r A$ gene was amplified with the mlas and $m c r A$-rev primer pair (Steinberg and Regan, 2009), with annealing at $57^{\circ} \mathrm{C}$. The bacterial $16 \mathrm{~S}$ rRNA gene was quantified with the primers Eub341F/Eub534R according to Degelmann et al. (2010), with annealing at $58^{\circ} \mathrm{C}$. Different DNA template concentrations were tested prior to the qPCR runs to determine optimal template concentration without inhibitions through co-extracts. The $25 \mu \mathrm{L}$ reactions contained $12.5 \mu \mathrm{L}$ of iTaq Universal SYBR Green Supermix (Bio-Rad, Munich, Germany), $0.25 \mu \mathrm{M}$ concentrations of the primers, and $5 \mu \mathrm{L}$ of DNA template. Data acquisition was always done at $80^{\circ} \mathrm{C}$ to avoid quantification of primer dimers. The specificity of each run was verified through melt-curve analysis and gel electrophoresis. Only runs with efficiencies between $82 \%$ and $105 \%$ were used for further analysis.
Measurements were performed in duplicates. The ratio of methanogens to methanotrophs was determined based on gene abundances of $m c r A$ and $p m o A$. The marker gene for the soluble monooxygenase, $m m o X$, was neglected due to the absence of Methylocella in the sequencing data (Fig. 4).

\subsection{Data visualization and statistical analysis}

All data visualization and statistical analysis were done in $\mathrm{R}$ (R Core Team, 2017). The taxonomic relative abundances across samples were visualized through bubble plots with the R package ggplot2 (Wickham, 2009). Differences in microbial community composition were visualized with twodimensional non-metric multidimensional scaling (NMDS) based on Bray-Curtis distances. The NMDS ordinations were constructed using $\mathrm{R}$ package vegan (Oksanen et al., 2017). An environmental fit was performed on the ordinations to determine the measured geochemical parameters that may influence community composition. The geochemical data were fitted to the ordinations as vectors with a significance of $p<0.05$. Depth profiles were constructed with the porewater geochemical data, as well as with the microbial abundances, to elucidate depth-wise trends and assess whether differences in microbial community and abundances 
among the two fens are related to differences in their respective geochemistry.

\section{Results}

\subsection{Environmental characteristics and site geochemistry}

The two rewetted fens varied substantially in their environmental characteristics (e.g., proximity to the sea) and porewater geochemistry (Fig. 2, Tables 1 and 2). EC was more than 3 times higher in Hütelmoor than in Zarnekow, averaging 5.3 and $1.5 \mathrm{mS} \mathrm{cm}^{-1}$, respectively. Mean values of $\mathrm{pH}$ were approximately neutral (6.5 to 7.0) in the upper peat profile and comparable in both fens until a depth of about $30 \mathrm{~cm}$ where $\mathrm{pH}$ decreased to $\sim 6$ in the Hütelmoor. Concentrations of the TEAs nitrate and sulfate were lower in Zarnekow and near zero in the pore water at all depths, while nitrate and sulfate were abundant in the upper and lower peat profile in Hütelmoor at $\sim 1.5$ to $3.0 \mathrm{mM}$ and $\sim 4$ to $20 \mathrm{mM}$, respectively (Fig. 2). Iron concentrations were higher in the Hütelmoor pore water, while manganese concentrations were higher in Zarnekow pore water. Dissolved oxygen concentrations in the upper peat profile (i.e., 0 to $25 \mathrm{~cm}$ depths) were much higher in Hütelmoor than in Zarnekow (Fig. 2). Here DO concentrations averaged $\sim 0.25 \mathrm{mM}$ until a depth of $15 \mathrm{~cm}$ at which they dropped sharply, reaching concentrations slightly below $0.05 \mathrm{mM}$ at $25 \mathrm{~cm}$. In Zarnekow, DO concentrations did not exceed $0.1 \mathrm{mM}$ and varied little with depth. Regarding geochemical conditions, Hütelmoor core (HC) 1 differed from all other Hütelmoor cores and was more similar to Zarnekow cores. In HC 1 - the core taken nearest to potential freshwater sources (Fig. 1b) - pore water $\mathrm{EC}$ and DO concentrations were lower while $\mathrm{pH}$ was slightly higher than in all other Hütelmoor cores. Moreover, this was the only Hütelmoor core where nitrate concentrations were below the detection limit $(0.001 \mathrm{mM})$ (Fig. 2). In all cores we found high concentrations of dissolved $\mathrm{CH}_{4}$ that varied within and among fens and were slightly higher in Zarnekow pore water. Stable isotope ratios of $\partial^{13} \mathrm{C}^{-} \mathrm{CH}_{4}$ (Fig. 2) in the upper peat (approx. $-59 \%$ ) suggest a predominance of acetoclastic methanogenesis, with a shift to hydrogenotrophic methanogenesis around $-65 \%$ in the lower peat profile. Additionally, the observed shifts toward less negative $\partial^{13} \mathrm{C}-\mathrm{CH}_{4}$ values in the upper peat layer, as in $\mathrm{HC} 1$ and $\mathrm{HC} 2$, could indicate partial oxidation of $\mathrm{CH}_{4}$ occurred (Chasar et al., 2000).

\subsection{Community composition of bacteria and archaea}

Bacterial sequences could be affiliated into a total of $30 \mathrm{bac}-$ terial phyla (Fig. 3). Among them, Proteobacteria, Acidobacteria, Actinobacteria, Chloroflexi, Nitrospirae, and Bacteroidetes were present in all samples. With mean relative abundance of $48 \%$, Proteobacteria was the most abun- dant phylum. Some taxa (e.g., Verrucomicrobia; Atribacteria, OP9; and AD3) were present only in Hütelmoor. Variation in community composition was larger in Hütelmoor samples than in Zarnekow. Within Proteobacteria, the alpha subdivision was the most dominant group, having contributed $26.7 \%$ to all the libraries on average (Fig. 4). The family Hyphomicrobiaceae dominated the Alphaproteobacteria and was distributed evenly across samples but missing in the surface and bottom peat layers in HC 2 . In addition, methanotrophs were clearly in low abundance across all samples, representing only $0.06 \%$ and $0.05 \%$ of the bacterial community in Hütelmoor and Zarnekow, respectively. Of the few methanotrophs that were detected, type II methanotrophs (mainly Methylocystaceae) outcompeted type I methanotrophs (mainly Methylococcaceae) in the community, while members of the genus Methylocella were absent (Fig. 4).

Within the archaeal community, Bathyarchaeota were mostly dominating over Euryarchaeota (Fig. 5). The miscellaneous Crenarchaeota group (MCG; mainly the order of pGrfC26) in Bathyarchaeota prevailed across all samples but was especially abundant in HC 2 samples. In addition to Bathyarchaeota, methanogenic archaea were important and on average contributed $30.6 \%$ to the whole archaeal community. Among the methanogens, acetoclastic methanogens were more abundant in most of the samples and Methanosaetaceae (24.8\%) were the major component. They were present in most samples and much more dominant than Methanosarcinaceae $(2.0 \%)$. Hydrogenotrophic methanogens, such as Methanomassiliicoccaceae (1.6\%), Methanoregulaceae (1.2\%), and Methanocellaceae (0.6\%), albeit low in abundance, were detected in many samples. Hütelmoor samples displayed greater variability in archaeal community composition compared to Zarnekow samples. The putative anaerobic methanotrophs of the ANME-2d (Raghoebarsing et al., 2006) clade occurred in patchy abundance with dominance in single spots of both sites. In HC 1 they represented a mean relative abundance of $40.9 \%$ of total archaeal reads but were almost absent in all other Hütelmoor cores. In Zarnekow core 3, ANME-2d represented up to approximately $30 \%$ of all archaea but were otherwise low in abundance.

\subsection{Environmental drivers of microbial community composition}

Bacterial and archaeal population at both peatland sites showed distinct clustering (Fig. 6) with similarly high intraand inter-site variations but greater overall variation in community composition in the Hütelmoor. Community composition varied much more strongly in $\mathrm{HC} 2$ than in any other core (Fig. 6). Bacterial communities in $\mathrm{HC} 1$ were more similar to communities in all Zarnekow cores than in other Hütelmoor cores (Fig. 6a). The archaeal community in HC 1 was more similar to Zarnekow cores as well (Fig. 6b). Environ- 


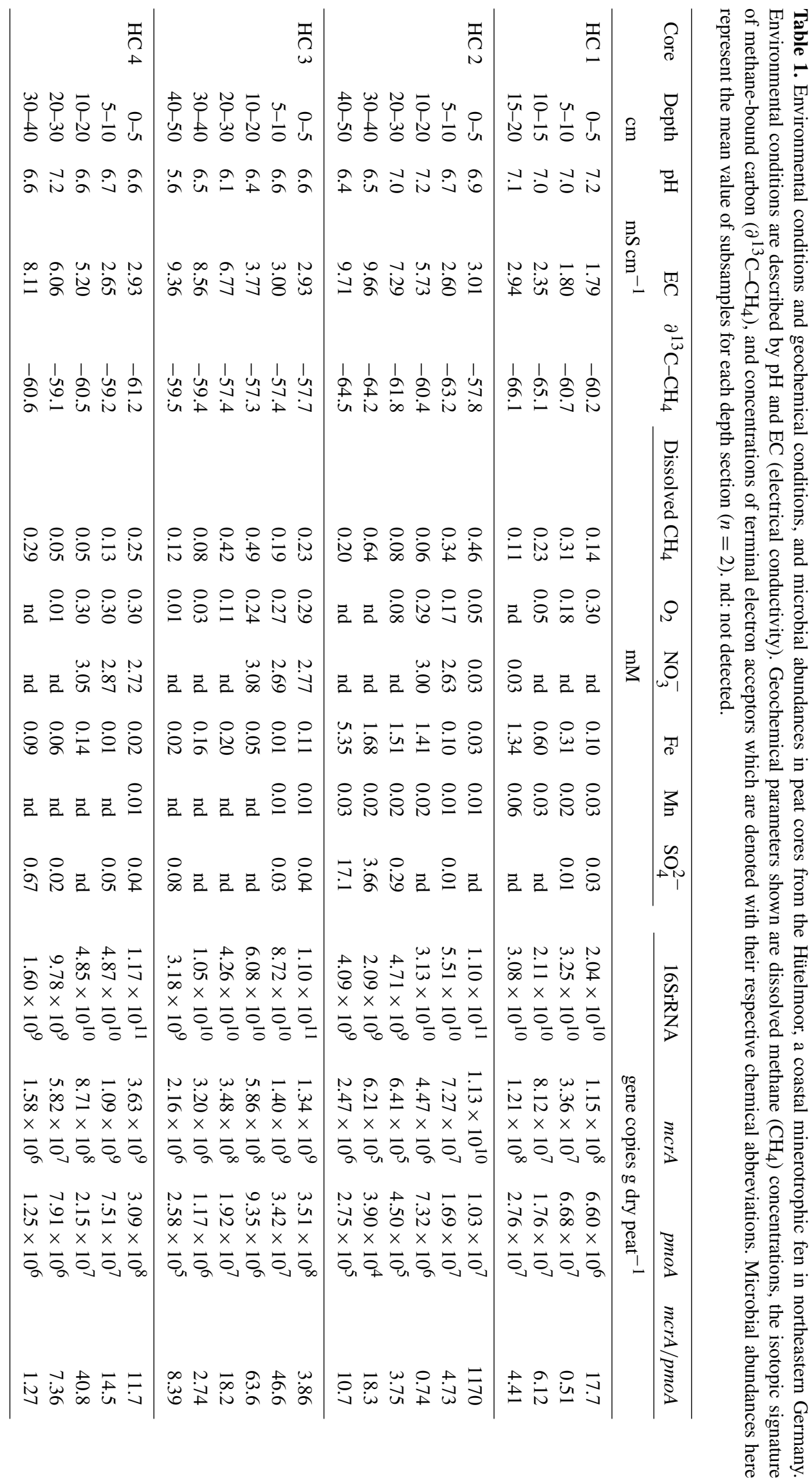




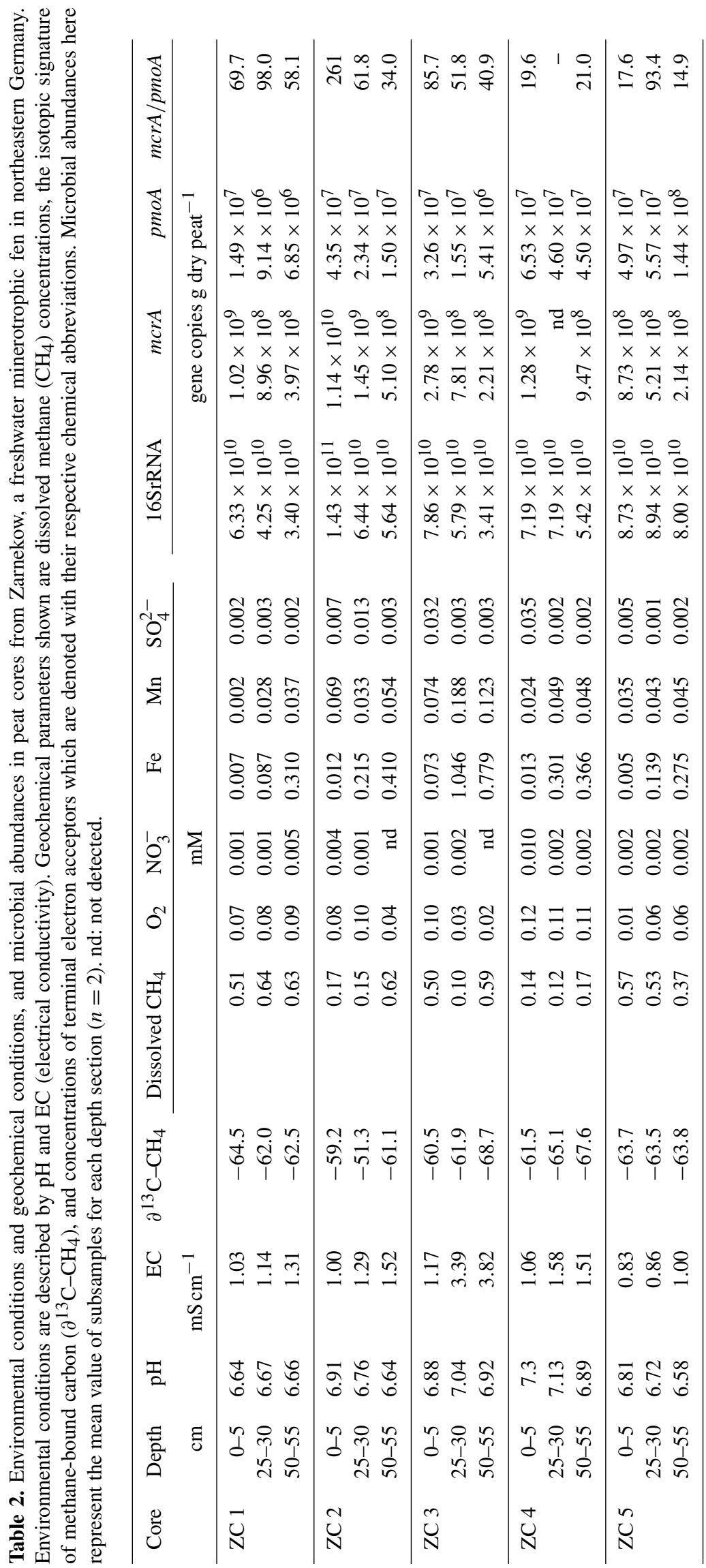




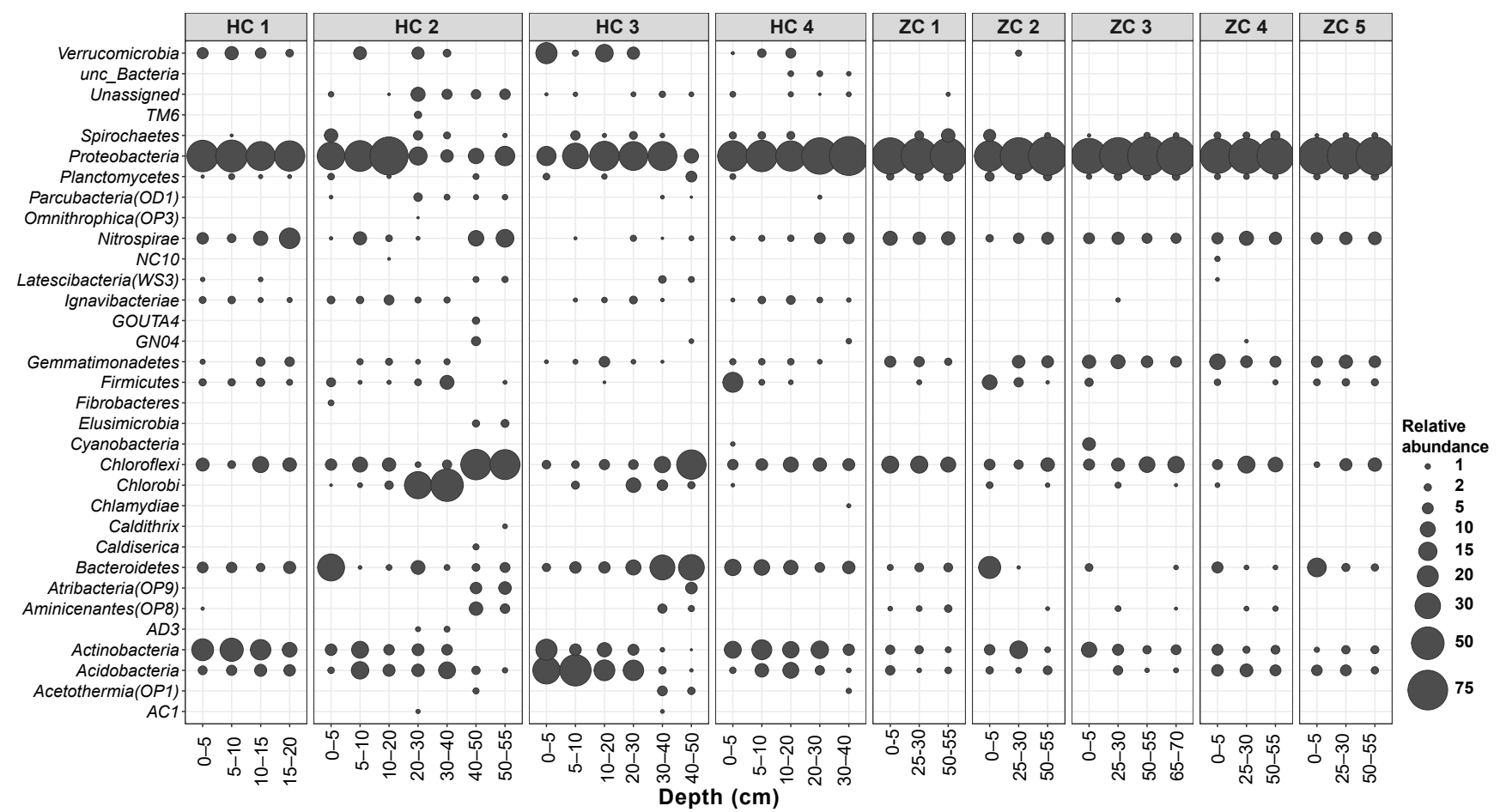

Figure 3. Relative abundances of different bacterial lineages in the study sites. Along the horizontal axis samples are arranged according to site and depth. The rank order along the vertical axis is shown for the phylum level.

mental fit vectors suggest $\mathrm{pH}$, oxygen, and alternative TEA availability as important factors influencing microbial community composition. The EC vector suggests the importance of brackish conditions in shaping microbial communities in the Hütelmoor (Fig. 6a-c).

\subsection{Total microbial and functional gene abundances}

Quantitative PCR results show that, in both fens, $m c r A$ abundance is up to 2 orders of magnitude greater than $p m o A$ abundance (Fig. 7, Tables 1 and 2). Gene copy numbers of $m c r A$ are overall higher and spatially more stable in Zarnekow than in Hütelmoor. Total microbial abundance declined with depth more strongly in Hütelmoor than in Zarnekow (Fig. 7). There was a pronounced decrease in microbial abundances at $20 \mathrm{~cm}$ depth in the Hütelmoor. For example, 16S rRNA gene and pmoA gene copy numbers in deeper samples (below $20 \mathrm{~cm}$ depth) are 1 order of magnitude lower than in upper samples on average, while the $m c r A$ gene abundances are approximately 2 orders of magnitude lower. Hütelmoor samples also exhibited larger heterogeneity in terms of abundances than Zarnekow samples. Contrary to previous studies, methanotroph abundance did not correlate with dissolved $\mathrm{CH}_{4}$ or oxygen concentrations.

\section{Discussion}

\subsection{Fen geochemistry and relations to microbial community composition}

The rewetting of drained fens promotes elevated $\mathrm{CH}_{4}$ production and emission, which can potentially offset carbon sink benefits. Few studies have attempted to link microbial community dynamics and site geochemistry with observed patterns in $\mathrm{CH}_{4}$ production and/or emission in rewetted fens, while such data are crucial for predicting long-term changes to $\mathrm{CH}_{4}$ cycling (Galand et al., 2002; Yrjälä et al., 2011; Juottonen et al., 2012). In this study, we show that $\mathrm{CH}_{4}$-cycling microbial community composition is related to patterns in site geochemistry in two rewetted fens with high $\mathrm{CH}_{4}$ emissions, high methanogen abundances, and low methanotroph abundances. Our results suggest that high methanogen abundances concurrent with low methanotroph abundances are characteristic of rewetted fens with ongoing high $\mathrm{CH}_{4}$ emissions. Thus, we present microbial evidence for sustained elevated $\mathrm{CH}_{4}$ emissions in mostly inundated rewetted temperate fens.

The environmental conditions and associated geochemistry of the two rewetted fens were largely different. Depth profiles of porewater geochemical parameters show the fens differed in EC throughout the entire peat profile, while $\mathrm{pH}$ and concentrations of alternative TEAs differed at certain 


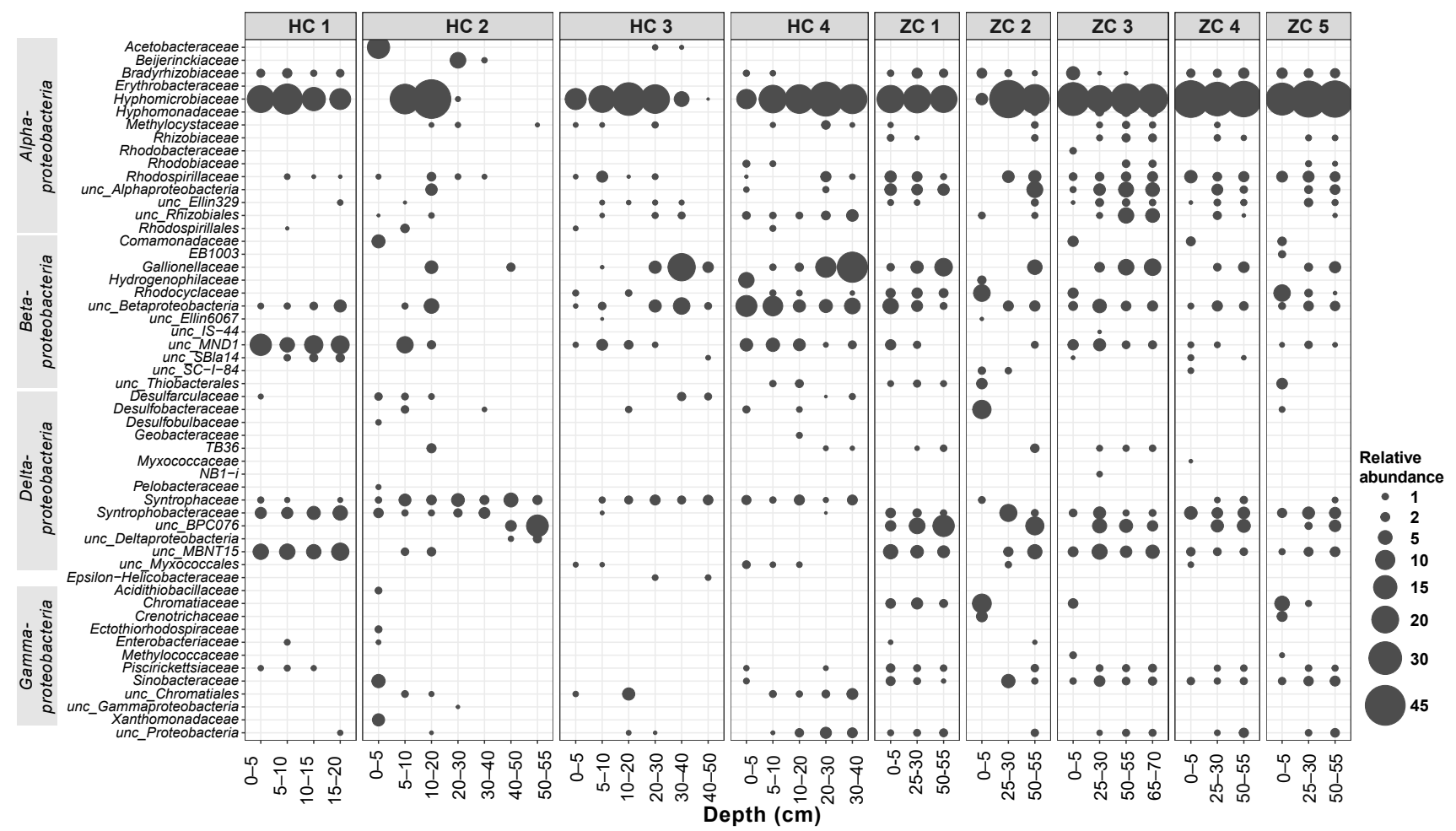

Figure 4. Relative abundances within Proteobacteria phylum in the study sites. Along the horizontal axis samples are arranged according to site and depth. The rank order along the vertical axis is shown for the family level. If an assignment to the family level was not possible the next higher assignable taxonomic level was used.

depths. In general, concentrations of TEAs oxygen, sulfate, nitrate, and iron were higher in the Hütelmoor. In Zarnekow, geochemical conditions varied little across the fen and along the peat depth profiles (Fig. 2). As expected, the geochemical heterogeneity was reflected in microbial community structure in both sites, suggesting the importance of environmental characteristics and associated geochemical conditions as drivers of microbial community composition (Figs. 2, 3, 4, 6). The NMDS ordinations (Fig. 6) show large variation in archaeal and bacterial community composition in the coastal brackish fen and much less variation in the freshwater riparian fen. Environmental fit vectors (Fig. 6) suggest that salinity (indicated by the $\mathrm{EC}$ vector), $\mathrm{pH}$, oxygen, and alternative TEA availability are the most important measured factors influencing microbial communities in the two fens. Patterns in microbial community composition have previously been linked to salinity (e.g., Chambers et al., 2016; Wen et al., 2017), pH (e.g., Yrjälä et al., 2011; Wen et al., 2017), and TEA availability in peatlands (e.g., He et al., 2015).

Comparing the geochemical depth profiles (Fig. 2) with the relative abundance of bacteria and archaea (Figs. 3 and 4) provides a more complete picture of the relationships between microbial communities and site geochemistry, particularly with respect to TEA utilization. While the porewater depth profiles suggest there is little nitrate available for microbial use in $\mathrm{HC} 1$, the relative abundance plot for $\mathrm{Ar}$ chaea showed that this core was dominated by ANME-2d. ANME-2d were recently discovered to be anaerobic methanotrophs that oxidize $\mathrm{CH}_{4}$, performing reverse methanogenesis using nitrate as an electron acceptor (Haroon et al., 2013). However, ANME-2d has also been implicated in the iron-mediated anaerobic oxidation of methane (Ettwig et al., 2016), and the HC 1 site showed slightly higher total iron concentrations. The relevance of ANME- $2 \mathrm{~d}$ as $\mathrm{CH}_{4}$ oxidizers in terrestrial habitats is still not clear (Winkel et al., 2018). Rewetting converts the fens into widely anaerobic conditions, thus providing conditions suitable for the establishment of anaerobic oxidation of methane, but this has yet to be demonstrated in fens. The patchy yet locally high abundance of ANME-2d both in Hütelmoor and in Zarnekow suggests an ecological relevance of this group. Shifts towards less negative $\delta^{13} \mathrm{C}_{-} \mathrm{CH}_{4}$ signatures in the upper peat profile, for example, from $-65 \%$ to $-60 \%$ in $\mathrm{HC} 1$ (where ANME-2d was abundant), may indicate that partial oxidation of $\mathrm{CH}_{4} \mathrm{oc}-$ curred, but we could only speculate whether or not ANME$2 \mathrm{~d}$ are actively involved in this $\mathrm{CH}_{4}$ oxidation.

Although TEA input may be higher in the Hütelmoor, here, methanogenic conditions also predominate. This finding contrasts the measured oxygen concentrations in the upper peat profile, as methanogenesis under persistently oxy- 


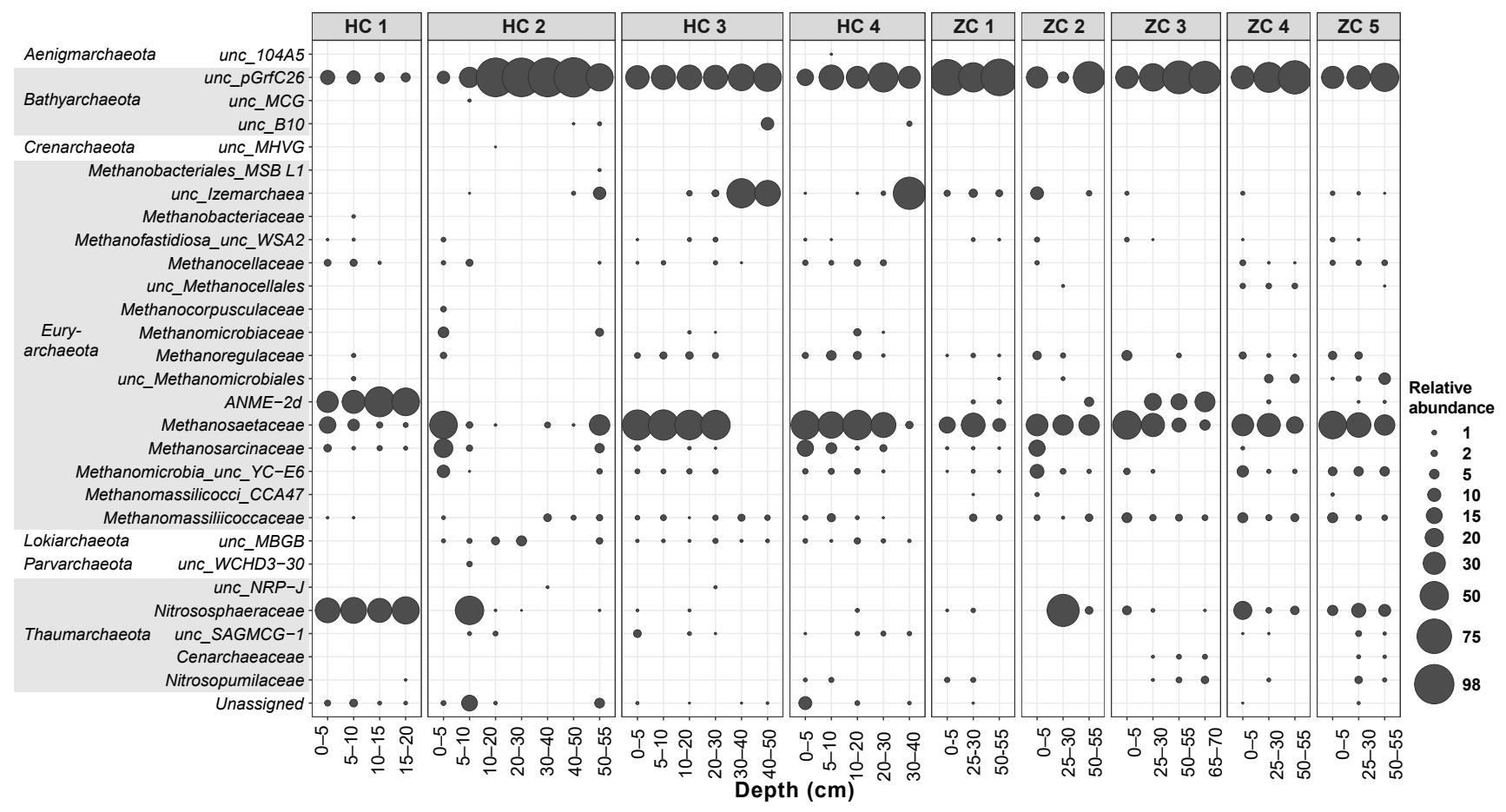

Figure 5. Relative abundances of different archaeal lineages in the study sites. Along the horizontal axis samples are arranged according to site and depth. The rank order along the vertical axis is shown for the family level. If an assignment to the family level was not possible, the next higher assignable taxonomic level was used.
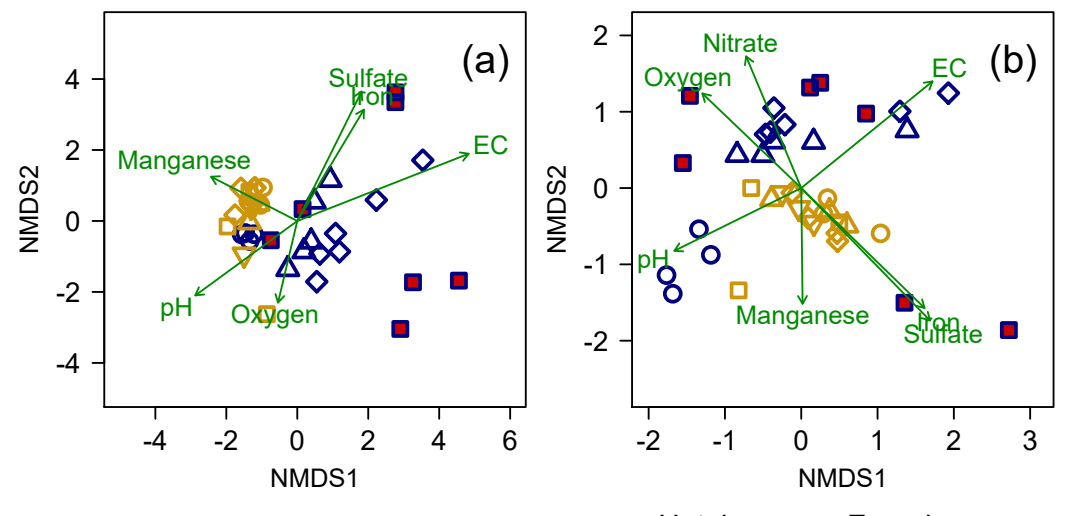

- Hütelmoor ○ Zarnekow

o Core 1 a Core $2 \diamond$ Core $3 \Delta$ Core $4 \nabla$ Core 5

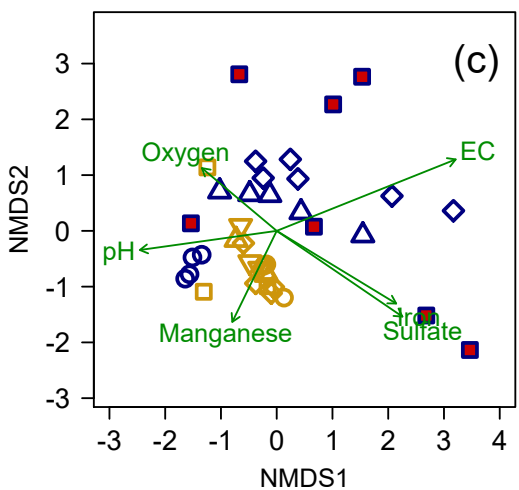

- Core 2 Hütelmoor

Figure 6. NMDS plots showing (a) bacterial, (b) archaeal, and (c) microbial (bacterial plus archaeal) community composition across the nine peat cores. The point positions represent distinct microbial communities, with the border colors of the symbols referring to the study sites and their shapes representing the core number. HC 2 symbols are highlighted with red fill to emphasize the large variation in microbial community within the core. Environmental fit vectors with a significance of $p<0.05$ are shown in green.

genated conditions is thermodynamically not possible. However, seasonal analysis of oxygen concentrations in both sites suggests highly fluctuating oxygen regimes both spatially and temporary (data not shown). Such nonuniform distribution of redox processes has already been described elsewhere, in particular for methanogenesis (Hoehler et al.,
2001; Knorr et al., 2009). It is possible that oxygen levels in both fens are highly variable, allowing for both aerobic and anaerobic carbon turnover processes. Recent studies from wetlands also show that methanogenesis can occur in aerobic layers, driven mainly by Methanosaeta (Narrowe et al., 2017; Wagner, 2017), which were detected in a high 

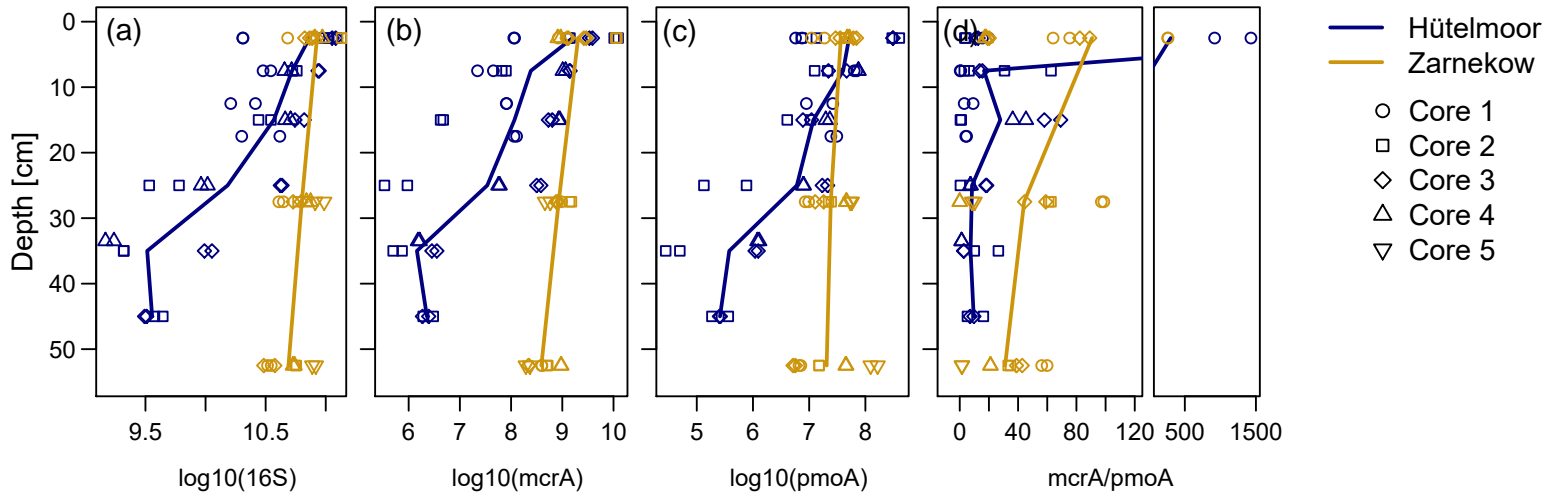

Figure 7. Depth distribution of qPCR abundances for total microbial (16S), methanogen ( $m c r A)$, methanotroph (pmoA), and ratio of $m c r A$ to $p m o A$ gene copy numbers in both sites. Microbial abundances were designated as numbers of gene copies per gram of dry peat soil. Duplicate measurements per depth section are shown against sampling depth using log-transformed values. Solid lines indicate mean abundances for individual wetlands ( $n=4$ for Hütelmoor and $n=5$ for Zarnekow). Note that the plot at the right was split into two plots to capture very high $m c r A / p m o A$ ratios in the upper peat layer.

abundance in this study (Fig. 5). Further, oxygen may not necessarily be available within aggregates entailing anaerobic pathways and, thus, the existence of anaerobic microenvironments may also partially explain the seemingly contradictory co-occurrence of oxygen and the highly abundant methanogens. Anaerobic conditions are also reflected by the extensive and stable occurrence of the strictly anaerobic syntrophs (e.g., Syntrophobacteraceae, Syntrophaceae) in most samples, even in the top centimeters. This suggests that syntrophic degradation of organic material is taking place in the uppermost layer and the fermented substances are readily available for methanogens. As geochemistry and microbial community composition differ among the sites in this study, it is thus notable that a similarly high abundance of methanogens, and low abundance of methanotrophs, was detected in both fens. The dominance of methanogens implies that readily available substrates and favorable geochemical conditions promote high anaerobic carbon turnover despite seasonally fluctuating oxygen concentrations in the upper peat layer.

\subsection{Low methanotroph abundances in rewetted fens}

Methanogens (mainly Methanosaetaceae) dominated nearly all of the various niches detected in this study, while methanotrophs were highly under-represented in both sites (Figs. 3 and 4). Functional and ribosomal gene copy numbers not only show a high ratio of methanogen to methanotroph abundance (Fig. 7), irrespective of site and time of sampling, but also a small contribution of methanotrophs to total bacterial population in both sites. Methanotrophs constitute only $\sim 0.06 \%$ of the total bacterial population in the Hütelmoor and $\sim 0.05 \%$ at Zarnekow. It should be noted that in this study we measured only gene abundances and not transcript abundances, and the pool both of active methanogens and methanotrophs was likely smaller than the numbers presented here (Freitag and Prosser, 2009; Freitag et al., 2010; Cheema et al., 2015; Franchini et al., 2015). Also, as we were unable to obtain microbial samples from before rewetting, a direct comparison of microbial abundances was not possible. This was, therefore, not a study of rewetting effects. For this reason, we performed an exhaustive literature search on relevant studies of pristine fens. Compared to pristine fens, we detected a low abundance of methanotrophs. Liebner et al. (2015), for example, found methanotrophs represented $0.5 \%$ of the total bacterial community in a pristine, subarctic transitional bog-fen palsa, while $m c r A$ and $p m o A$ abundances were nearly identical. In a pristine Swiss alpine fen, Liebner et al. (2012) found methanotrophs generally outnumbered methanogens by an order of magnitude. Cheema et al. (2015) and Franchini et al. (2015) reported mcrA abundances higher than pmoA abundances by only 1 order of magnitude in a separate Swiss alpine fen. In the rewetted fens in our study, mcrA gene abundance was up to 2 orders of magnitude higher than $p m o A$ abundance (Fig. 7). Due to inevitable differences in methodology and equipment, direct comparisons of absolute gene abundances are limited. Therefore, only the abundances of methanotrophs relative to methanogens and relative to the total bacterial community were compared, rather than absolute abundances. We are confident that this kind of "normalization" can mitigate the bias of different experiments and allows a comparison of sites. Further, all primers and equipment used in this study were identical to those used by Liebner et al. $(2012,2015)$, making the comparison more reliable.

As most methanotrophs live along the oxic-anoxic boundary of the peat surface and plant roots therein (Le Mer and Roger, 2001), the low methanotroph abundances in both fens could be explained by disturbances to this boundary 
zone and associated geochemical pathways following inundation. In rewetted fens, a massive plant dieback has been observed along with strong changes in surface peat geochemistry (Hahn-Schöfl et al., 2011; Hahn et al., 2015). In addition to substrate (i.e., $\mathrm{CH}_{4}$ ) availability, oxygen availability is the most important factor governing the activity of most methanotrophs (Le Mer and Roger, 2001; Hernandez et al., 2015). The anoxic conditions at the peat surface caused by inundation may have disturbed existing methanotrophic niches either directly by habitat destruction and/or indirectly by promoting the growth of organisms that are able to outcompete methanotrophs for oxygen. Heterotrophic organisms, for example, have been shown to outcompete methanotrophs for oxygen when oxygen concentrations are greater than $5 \mu \mathrm{M}$ (van Bodegom et al., 2001). Our microbial data support this conclusion, as Hyphomicrobiaceae, most of which are aerobic heterotrophs, was the most abundant bacterial family in both fens. Incubation data from Zarnekow (Fig. S1 in the Supplement) show that the $\mathrm{CH}_{4}$ oxidation potential is high; however, incubations provide ideal conditions for methanotrophs and thus only potential rates. It is likely that, in situ, the activity of methanotrophs is overprinted by the activity of competitive organisms such as heterotrophs. It is also possible that methane oxidation may occur in the water column above the peat surface, but this was beyond the scope of this study. Nevertheless, oxidation rates are low enough that emissions remain high, as demonstrated by the high dissolved $\mathrm{CH}_{4}$ concentrations and ongoing high fluxes.

Comparable studies have so far been conducted in nutrient-poor or mesotrophic fens where post-rewetting $\mathrm{CH}_{4}$ emissions, though higher than pre-rewetting, did not exceed those of similar pristine sites (e.g., Yrjälä et al., 2011; Juottonen et al., 2005, 2012). Nevertheless, there is mounting evidence linking $\mathrm{CH}_{4}$-cycling microbe abundances to $\mathrm{CH}_{4}$ dynamics in rewetted fens. Juottonen et al. (2012), for example, compared $p m o A$ gene abundances in three natural and three rewetted fens and found them to be lower in rewetted sites. The same study also measured a lower abundance of $m c r A$ genes in rewetted sites, which was attributed to a lack of available labile organic carbon compounds. In peatlands, and especially fens, litter and root exudates from vascular plants can stimulate $\mathrm{CH}_{4}$ emissions (Megonigal et al., 2005; Bridgham et al., 2013; Agethen and Knorr, 2018), and excess labile substrate has been proposed as one reason for substantial increases in $\mathrm{CH}_{4}$ emissions in rewetted fens (HahnSchöfl et al., 2011). Future studies should compare pre- and post-rewetting microbial abundances along with changes in $\mathrm{CH}_{4}$ emissions, plant communities, and peat geochemistry to better assess the effect rewetting has on the $\mathrm{CH}_{4}$-cycling microbial community.

\section{Conclusion}

Despite a recent increase in the number of rewetting projects in northern Europe, few studies have characterized $\mathrm{CH}_{4}$ cycling microbes in restored peatlands, especially fens. In this study, we show that rewetted fens differing in geochemical conditions and microbial community composition have a similarly low abundance of methanotrophs, a high abundance of methanogens, and an established anaerobic carboncycling microbial community. Comparing these data to pristine wetlands with lower $\mathrm{CH}_{4}$ emission rates, we found that pristine wetlands have a higher abundance of methanotrophs than measured in the fens in this study, suggesting the inundation and associated anoxia caused by flooding may disturb methanotrophic niches and negatively affect the ability of methanotrophic communities to establish. The abundances of methane producers and consumers are thus suggested as indicators of continued elevated $\mathrm{CH}_{4}$ emissions following the rewetting of drained fens. Management decisions regarding rewetting processes should consider that disturbances to methanotrophic niches are possible if rewetting leads to longterm inundation of the peat surface.

Data availability. The $16 \mathrm{~S}$ rRNA gene sequence data have been deposited at NCBI under the BioProject PRJNA356778. The Hütelmoor sequence read archive accession numbers are SRR5118134SRR5118155 for bacterial and SRR5119428-SRR5119449 for archaeal sequences. The Zarnekow accession numbers are SRR6854018-SRR6854033 and SRR6854205-SRR6854220 for bacterial and archaeal sequences, respectively (https://www. ncbi.nlm.nih.gov/bioproject/PRJNA356778, last access: 25 October 2018).

Supplement. The supplement related to this article is available online at: https://doi.org/10.5194/bg-15-6519-2018-supplement.

Author contributions. FK, SL, GJ, XW, and VU formulated the research questions and study design. FK, MW, SL, and TS performed field work. SL, GJ, XW, VU, and TS visualized the data and prepared maps. SL, MEB, KHK, GL, and DZ provided analytical data measurements. FH conducted the bioinformatics analyses. PLEB provided the incubation data and prepared the Supplement figure. All authors contributed to the discussion and interpretation of the data and the writing of the paper. VU and XW contributed equally to the writing of the paper and prepared the original draft.

Competing interests. The authors declare that they have no conflict of interest.

Acknowledgements. This study was conducted within the framework of the Research Training Group "Baltic TRANSCOAST" funded by the DFG (Deutsche Forschungsgemeinschaft) under 
grant number GRK 2000. This is Baltic TRANSCOAST publication no. GRK2000/000X. The financial support to Xi Wen (grant no. 201408620031) provided by the China Scholarship Council (CSC), and to Matthias Winkel (ARCSS-1500931) provided by the National Science Foundation (NSF), is gratefully acknowledged. This study was supported by the Helmholtz Gemeinschaft (HGF) by funding the Helmholtz Young Investigators Group of Susanne Liebner (VH-NG-919) and Torsten Sachs (grant VH-NG821), a Helmholtz Postdoc Programme grant to Franziska Koebsch (grant PD-129), and further supported by the Terrestrial Environmental Observatories (TERENO) Network. The Leibniz Institute for Baltic Sea Research (IOW) is also acknowledged for funding the lab work in this study. The European Social Fund (ESF) and the Ministry of Education, Science and Culture of MecklenburgWestern Pomerania funded this work within the scope of the project WETSCAPES (ESF/14-BM-A55-0030/16). Matthias Gehre, head of the Laboratory of Stable Isotopes at the Helmholtz Centre for Environmental Research, is acknowledged for providing carbon isotope measurements for this study. Anke Saborowski and Anne Köhler are also acknowledged for support in the laboratory.

The article processing charges for this open-access publication were covered by a Research

Centre of the Helmholtz Association.

Edited by: Tina Treude

Reviewed by: three anonymous referees

\section{References}

Abdalla, M., Hastings, A., Truu, J., Espenberg, M., Mander, U., and Smith, P.: Emissions of methane from northern peatlands: a review of management impacts and implications for future management options, Ecol. Evol., 6, 7080-7102, https://doi.org/10.1002/ece3.2469, 2016.

Agethen, S. and Knorr, K.-H.: Juncus effusus mono-stands in restored cutover peat bogs - Analysis of litter quality, controls of anaerobic decomposition, and the risk of secondary carbon loss, Soil Biology and Biochemistry, 117, 139-152, https://doi.org/10.1016/j.soilbio.2017.11.020, 2018.

Augustin, J. and Chojnicki, B.: Austausch von klimarelevanten Spurengasen, Klimawirkung und Kohlenstoffdynamik in den ersten Jahren nach der Wiedervernässung von degradiertem Niedermoorgrünland (Exchange of climate relevant trace gases, climate effect and carbon dynamics in the first years after re-wetting of degraded fen grassland), in: Phosphor- und Kohlenstoff- Dynamik und Vegetationsentwicklung in wiedervernässten Mooren des Peenetals in Mecklenburg-Vorpommern (Phosphorus and carbon dynamics and vegetation development in re-wetted peatland of the Peene valley in Mecklenburg-Western Pomerania), edited by: Gelbrecht, J., Zak, D., and Augustin, J., LeibnizInstitut für Gewässerökologie und Binnenfischerei, Berlin, 5067, 2008 (in German).

Augustin, J., Merbach, W., and Rogasik, J.: Factors influencing nitrous oxide and methane emissions from minerotrophic fens in northeast Germany, Biol. Fert. Soils, 28, 1-4, https://doi.org/10.1007/s003740050455, 1998.
Blodau, C.: Thermodynamic control on terminal electron transfer and methanogenesis, in: Aquatic Redox Chemistry, ACS Symposium Series, edited by: Tratnyek, P. G., Grundl, T. J., and Haderlein, S. B., American Chemical Society, Oxford University Press Inc., Washington, D.C., 65-82, https://doi.org/10.1021/bk-20111071.ch004, 2011.

Bolger, A. M., Lohse, M., and Usadel, B.: Trimmomatic: a flexible trimmer for Illumina sequence data, Bioinformatics, 30, 21142120, https://doi.org/10.1093/bioinformatics/btu170, 2014.

Bridgham, S. D., Cadillo-Quiroz, H., Keller, J. K., and Zhuang, Q.: Methane emissions from wetlands: biogeochemical, microbial, and modeling perspectives from local to global scales, Global Change Biol., 19, 1325-1356, https://doi.org/10.1111/gcb.12131, 2013.

Cadillo-Quiroz, H., Yashiro, E., Yavitt, J. B., and Zinder, S. H.: Characterization of the archaeal community in a minerotrophic fen and terminal restriction fragment length polymorphism-directed isolation of a novel hydrogenotrophic methanogen, Appl. Environ. Microb. 74, 2059-2068, https://doi.org/10.1128/AEM.02222-07, 2008.

Caporaso, J. G., Kuczynski, J., Stombaugh, J., Bittinger, K., Bushman, F. D., Costello, E. K., Fierer, N., Peña, A. G., Goodrich, J. K., Gordon, J. I., Huttley, G. A., Kelley, S. T., Knights, D., Koenig, J. E., Ley, R. E., Lozupone, C. A., McDonald, D., Muegge, B. D., Pirrung, M., Reeder, J., Sevinsky, J. R., Turnbaugh, P. J., Walters, W. A., Widmann, J., Yatsunenko, T., Zaneveld, J., and Knight, R.: QIIME allows analysis of highthroughput community sequencing data, Nat. Methods, 7, 335336, https://doi.org/10.1038/nmeth.f.303, 2010.

Chambers, L. G., Guevara, R., Boyer, J. N., Troxler, T. G., and Davis, S. E.: Effects of salinity and inundation on microbial community structure and function in a mangrove peat soil, Wetlands, 36, 361-371, https://doi.org/10.1007/s13157-016-0745-8, 2016.

Chasar, L. S., Chanton, J. P., Glaser, P. H., and Siegel, D. I.: Methane concentration and stable isotope distribution as evidence of rhizospheric processes: comparison of a fen and bog in the Glacial Lake Agassiz Peatland complex, Ann. Bot.-London, 86, 655663, https://doi.org/10.1006/anbo.2000.1172, 2000.

Cheema, S., Zeyer, J., and Henneburger, R.: Methanotrophic and methanogenic communities in Swiss alpine fens dominated by Carex rostrata and Eriphorum angustifolium, Appl. Environ. Microb., 81, 5832-5844, https://doi.org/10.1128/AEM.01519-15, 2015.

Conrad, R.: Soil microorganisms as controllers of atmospheric trace gases $\left(\mathrm{H}_{2}, \mathrm{CO}, \mathrm{CH}_{4}, \mathrm{OCS}, \mathrm{N}_{2} \mathrm{O}\right.$, and $\left.\mathrm{NO}\right)$, Microbiol. Rev., 60, 609-640, 1996.

Degelmann, D. M., Borken, W., Drake, H. L., and Kolb, S.: Different atmospheric methane-oxidizing communities in European beech and Norway spruce soils, Appl. Environ. Microb., 76, 3228-3235, https://doi.org/10.1128/AEM.02730-09, 2010.

Emsens, W.-J., Aggenbach, C. J. S., Schoutens, K., Smolders, A. J. P., Zak, D., and van Diggelen, R.: Soil iron content as a predictor of carbon and nutrient mobilization in rewetted fens, PLoS ONE, 11, e0153166, https://doi.org/10.1371/journal.pone.0153166, 2016.

Ettwig, K. F., Zhu, B., Speth, D., Keltjens, J. T., Jetten, M. S. M., and Kartal, B.: Archaea catalyze iron-dependent anaerobic oxidation of methane, P. Natl. Acad. Sci. USA, 113, 12792-12796, https://doi.org/10.1073/pnas.1609534113, 2016. 
Franchini, A. G., Henneberger, R., Aeppli, M., and Zeyer, J.: Methane dynamics in an alpine fen: a field-based study on methanogenic and methanotrophic microbial communities, FEMS Microbiology Ecology, 91, 1-13, https://doi.org/10.1093/femsec/fiu032, 2015.

Franz, D., Koebsch, F., Larmanou, E., Augustin, J., and Sachs, T.: High net $\mathrm{CO}_{2}$ and $\mathrm{CH}_{4}$ release at a eutrophic shallow lake on a formerly drained fen, Biogeosciences, 13, 3051-3070, https://doi.org/10.5194/bg-13-3051-2016, 2016.

Freitag, T. E. and Prosser, J. I.: Correlation of methane production and functional gene transcription activity in a peat soil, Appl. Environ. Microb., 75, 6679-6687, https://doi.org/10.1128/AEM.01021-09, 2009.

Freitag, T. E., Toet, S., Ineson, P., and Prosser, J. I.: Links between methane flux and transcriptional activities of methanogens and methane oxidizers in a blanket peat bog, FEMS Microbiology Ecology, 73, 157-165, https://doi.org/10.1111/j.15746941.2010.00871.x, 2010.

Galand, P. E., Saarnio, S., Fritze, H., and Yrjälä, K.: Depth related diversity of methanogen Archaea in Finnish oligotrophic fen, FEMS Microbiology Ecology, 42, 441-449, https://doi.org/10.1111/j.1574-6941.2002.tb01033.x, 2002.

Galand, P. E., Fritze, H., Conrad, R., and Yrjälä, K.: Pathways for methanogenesis and diversity of methanogenic archaea in three boreal peatland ecosystems, Appl. Environ. Microb., 71, 21952198, https://doi.org/10.1128/AEM.71.4.2195-2198.2005, 2005.

Hahn, J., Köhler, S., Glatzel, S., and Jurasinski, G.: Methane exchange in a coastal fen the first year after flooding - a systems shift, PLoS ONE, 10, e0140657, https://doi.org/10.1371/journal.pone.0140657, 2015.

Hahn-Schöfl, M., Zak, D., Minke, M., Gelbrecht, J., Augustin, J., and Freibauer, A.: Organic sediment formed during inundation of a degraded fen grassland emits large fluxes of $\mathrm{CH} 4$ and CO2, Biogeosciences, 8, 1539-1550, https://doi.org/10.5194/bg8-1539-2011, 2011.

Haroon, M. F., Hu, S., Shi, Y., Imelfort, M., Keller, J., Hugenholtz, P., Yuan, Z., and Tyson, G.: Anaerobic oxidation of methane couple to nitrate reduction in a novel archaeal lineage, Nature, 500, 567-570, https://doi.org/10.1038/nature12375, 2013.

He, S., Malfatti, S. A., McFarland, J. W., Anderson, F. E., Pati, A., Huntemann, M., Tremblay, J., del Rio, T. G., Waldrop, M. P., Windham-Myers, L., and Tringe, S. G.: Patterns in wetland microbial community composition and functional gene repertoire associated with methane emissions, mBio, 6, 1-15, https://doi.org/10.1128/mBio.00066-15, 2015.

Herlemann, D. P., Labrenz, M., Jürgens, K., Bertilsson, S., Waniek, J. J., and Andersson, A. F.: Transitions in bacterial communities along the $2000 \mathrm{~km}$ salinity gradient of the Baltic Sea, ISME J., 5 , 1571-1579, https://doi.org/10.1038/ismej.2011.41, 2011.

Hernandez, M. E., Beck, D. A., Lidstrom, M. E., and Chistoserdova, L.: Oxygen availability is a major factor in determining the composition of microbial communities involved in methane oxidation, PeerJ, 3, e801, https://doi.org/10.7717/peerj.801, 2015.

Hoehler, T. M., Alperin, M. J., Albert, D. B., and Martens, C. S.: Apparent minimum free energy requirements for methanogenic Archaea and sulfate-reducing bacteria in an anoxic marine sediment, FEMS Microbiology Ecology, 38, 33-41, https://doi.org/10.1016/S0168-6496(01)00175-1, 2001.
Jerman, V., Metje, M., Mandic-Mulec, I., and Frenzel, P.: Wetland restoration and methanogenesis: the activity of microbial populations and competition for substrates at different temperatures, Biogeosciences, 6, 1127-1138, https://doi.org/10.5194/bg6-1127-2009, 2009.

Joosten, H., Brust, K., Couwenberg, J., Gerner, A., Holsten, B., Permien, T., Schäfer, A., Tanneberger, F., Trepel, M., and Wahren, A.: MoorFutures ${ }^{\circledR}$ Integration of additional ecosystem services (including biodiversity) into carbon credits - standard, methodology and transferability to other regions, Bundesamt für Naturschutz (Federal Ministry for the Environment, BfN), BfNSkripten 407, Bonn, Germany, 2015.

Juottonen, H., Galand, P. E., Tuittila, E.-S., Laine, J., Fritze, H., and Yrjälä, K.: Methanogen communities and bacteria along an ecohydrological gradient in a northern raised bog complex, Environ. Microbiol., 7, 1547-1557, https://doi.org/10.3389/fmicb.2015.00356, 2005.

Juottonen, H., Hynninen, A., Nieminen, M., Tuomivirta, T. T., Tuittila, E.-S., Nousiainen, H., Kell, D. K., Yrjälä, K., Tervahauta, A., and Fritze, H.: Methane-cycling microbial communities and methane emission in natural and restored peatlands, Appl. Environ. Microb., 78, 6386-6389, https://doi.org/10.1128/AEM.00261-12, 2012.

Jurasinski, G., Glatzel, S., Hahn, J., Koch, S., Koch, M., and Koebsch, F.: Turn on, fade out - Methane exchange in a coastal fen over a period of six years after rewetting, Geophys. Res. Abstr., 18, EGU2016-14899, 2016.

Keller, J. K. and Bridgham, S. D.: Pathways of anaerobic carbon cycling across an ombrotrophic-minerotrophic peatland gradient, Limnol. Oceanogr., 52, 96-107, https://doi.org/10.4319/lo.2007.52.1.0096, 2007.

Kelly, C. A., Dice, N. B., and Martens, C. S.: Temporal variations in the stable carbon isotopic composition of methane emitted from Minnesota peatlands, Global Biogeochem. Cy., 6, 263-269, https://doi.org/10.1029/92GB01478, 1992.

Knorr, K.-H. and Blodau, C.: Impact of experimental drought and rewetting on redox transformations and methanogenesis in mesocosms of a northern fen soil, Soil Biology and Biochemistry, 41, 1187-1198, https://doi.org/10.1016/j.soilbio.2009.02.030, 2009.

Knorr, K.-H., Lischeid, G., and Blodau, C.: Dynamics of redox processes in a minerotrophic fen exposed to a water table manipulation, Geoderma, 153, 379-392, https://doi.org/10.1016/j.geoderma.2009.08.023, 2009.

Koch, M., Koebsch, F., Hahn, J., and Jurasinski, G.: From meadow to shallow lake: Monitoring secondary succession in a coastal fen after rewetting by flooding based on aerial imagery and plot data, Mires Peat, 19, 1-17, https://doi.org/10.19189/MaP.2015.OMB.188, 2017.

Koebsch, F., Glatzel, S., and Jurasinski, G.: Vegetation controls emissions in a coastal brackish fen, Wetl. Ecol. Manag., 21, 323337, https://doi.org/10.1007/s11273-013-9304-8, 2013.

Koebsch, F., Jurasinski, G., Koch, M., Hofmann, J., and Glatzel, S.: Controls for multi-scale temporal variation in ecosystem methane exchange during the growing season of a permanently inundated fen, Agr. Forest Meteorol., 204, 94-105, https://doi.org/10.1016/j.agrformet.2015.02.002, 2015.

Kolb, S., Knief, C., Stubner, S., and Conrad, R.: Quantitative detection of methanotrophs in soil by novel pmoA-targeted 
real-time PCR assays, Appl. Environ. Microb., 69, 2423-2429, https://doi.org/10.1128/AEM.69.5.2423-2429.2003, 2003.

Komulainen, V.-M., Nykanen, H., Martikainen, P. J., and Laine, J.: Short-term effect of restoration on vegetation change and methane emissions from peatlands drained for forestry in southern Finland, Can. J. Forest Res., 28, 402-411, https://doi.org/10.1139/x98-011, 1998.

Kowalski, N., Dellwig, O., Beck, M., Grunwald, M., Dürselen, CD., Badewien, T. H., Brumsack, H-J., van Beusekom, J. E. E., and Böttcher, M. E.: A comparative study of manganese dynamics in the water column and sediments of intertidal systems of the North Sea, Estuarine, Coast. Shelf Sci., 100, 3-17, https://doi.org/10.1016/j.ecss.2011.03.011, 2012.

Le Mer, J. and Roger. P.: Production, oxidation, emission, and consumption of methane by soils: a review, Eur. J. Soil Biol., 37, 25-50, https://doi.org/10.1016/S1164-5563(01)01067-6, 2001.

Liebner, S., Schwarzenbach, S. P., and Zeyer, J.: Methane emissions from an alpine fen in central Switzerland, Biogeochemistry, 109, 287-299, https://doi.org/10.1007/s10533-011-9629-4, 2012.

Liebner, S., Ganzert, L., Kiss, A., Yang, S., Wagner, D., and Svenning, M. M.: Shifts in methanogenic community composition and methane fluxes along the degradation of discontinuous permafrost, Front. Microbiol., 6, 1-10, https://doi.org/10.3389/fmicb.2015.00356, 2015.

Liu, D. Y., Ding, W. X., Jia, Z. J., and Cai, Z. C.: Relation between methanogenic archaea and methane production potential in selected natural wetland ecosystems across China, Biogeosciences, 8, 329-338, https://doi.org/10.5194/bg-8-329-2011, 2011.

Martin, M.: Cutadapt removes adapter sequences from highthroughput sequencing reads, EMBnet. Journal, 17, 10-12, https://doi.org/10.14806/ej.17.1.200, 2011.

McDonald, D., Price, M. N., Goodrich, J., Nawrocki, E. P., DeSantis, T. Z., Probst, A., Andersen, G. L., Knight, R., and Hugenholtz, P.: An improved Greengenes taxonomy with explicit ranks for ecological and evolutionary analyses of bacteria and archaea, ISME J,, 6, 610-618, https://doi.org/10.1038/2Fismej.2011.139, 2012.

Megonigal, J. P., Mines, M. E., and Visscher, P. T.: Anaerobic metabolism: linkages to trace gases and aerobic processes, in: Biogeochemistry, edited by: Schlesinger, W. H., Elsevier, Oxford, UK, 350-362, 2005.

Minke, M., Augustin, J., Burlo, A., Yarmashuk, T., Chuvashova, H., Thiele, A., Freibauer, A., Tikhonov, V., and Hoffmann, M.: Water level, vegetation composition, and plant productivity explain greenhouse gas fluxes in temperate cutover fens after inundation, Biogeosciences, 13, 3945-3970, https://doi.org/10.5194/bg-133945-2016, 2016.

Myhre, G., Shindell, D., Breon, F.-M., Collins, W., Fuglestvedt, J., Huang, J., Koch, D., Lamarque, J.-F., Lee, D., Mendoza, B., Nakajima, T., Robock, A., Rotstayn, L., Stephens, G., and Zhang, H.: Anthropogenic and natural radiative forcing. Chapter 8, in: Climate Change 2013. The Physical Science Basis. Contribution of Working Group I to the Fifth Assessment Report of the Intergovermental Panel on Climate Change, edited by: Stocker, T. F., Qin, D., Plattner, G.-K., Tignor, M., Allen, D., Boschung, J., Nauels, A., Xia, Y., Bex, V., and Midgley, P. M., Cambridge University Press, Cambridge, UK and New York, USA, 659-740, 2013.
Narrowe, A. B., Angle, J. C., Daly, R. A., Stefanik, K. C., Wrighton, K. C., and Miller, C. S.: High-resolution sequencing reveals unexplored archaeal diversity in freshwater wetland soils, Environ. Microbiol., 19, 2192-2209, https://doi.org/10.1111/14622920.13703, 2017.

Oksanen, J., Blanchet, F. G., Friendly, M., Kindt, R., Legendre, P., McGlinn, D., Minchin, P. R., O’Hara, R. B., Simpson, G. L., Solymos, Stevens, M. H. H., Szoecs, E., and Wagner, H.: vegan: Community Ecology Package, R package version 2.4-5, available at: https://CRAN.R-project.org/package=vegan (last access: 1 October 2018), 2017.

Putkinen, A., Tuittila, E.-S., Siljanen, H. M. P., Bodrossy, L., and Fritze, H.: Recovery of methane turnover and the associated microbial communities in restored cutover peatlands is strongly linked with increasing sphagnum abundance, Soil Biology and Biochemistry, 116, 110-119, https://doi.org/10.1016/j.soilbio.2017.10.005, 2018.

Quast, C., Pruesse, E., Yilmaz, P., Gerken, J., Schweer, T., Yarza, P., Peplies, J., and Glöckner, F. O.: The SILVA ribosomal RNA gene database project: improved data processing and web-based tools, Nucleic Acids Res., 41, D590-596, https://doi.org/10.1093/nar/gks1219, 2013.

Raghoebarsing, A. A., Pol, A., van de Pas-Schoonen, K. T., Smolders, A. J. P., Ettwig, K. F., Rijpstra, W. I. C., Schouten, S., Damste, J. S. S., Op den Camp, H. J. M., Jetten, M. S. M., and Strous, M.: A microbial consortium couples anaerobic methane oxidation to denitrification, Nature, 440, 918-921, https://doi.org/10.1038/nature04617, 2006.

R Core Team: R: A language and environment for statistical computing. R Foundation for Statistical Computing, Vienna, Austria, available at: https://www.R-project.org/ (last access: 1 October 2018), 2017.

Schemel, L.: Simplified conversions between specific conductance and salinity units for use with data from monitoring stations, Interagency Ecological Program Newsletter, 14, 17-18, 2001.

Schönfeld-Bockholt, R., Roth, D., and Dittmann, L.: Ch. Teilflächenbezogene ökologische und futterwirtschaftliche Beurteilung des Grünlandes im Naturschutzgebiet Heiligensee und Hütelmoor, in: Effiziente Nutzung von Grünland als Ressource für die Milch- und Fleischproduktion Mitteilungen der Arbeitsgemeinschaft Grünland und Futterbau, Zollikofen, Switzerland, 2008.

Segers, R.: Methane production and methane consumption: a review of processes underlying wetland methane fluxes, Biogeochemistry, 41, 23-51, https://doi.org/10.1023/A:1005929032764, 1998.

Steffenhagen, P., Zak, D., Schulz, K., Timmerman, T., and Zerbe, S.: Biomass and nutrient stock of submersed and floating macrophytes in shallow lakes formed by rewetting of degraded fens, Hydrobiologia, 692, 99-109, https://doi.org/10.1007/s10750011-0833-y, 2012.

Steinberg, L. M. and Regan, J. M.: mcrA-targeted realtime quantitative PCR method to examine methanogen communities, Appl. Environ. Microb., 75, 4435-4442, https://doi.org/10.1128/AEM.02858-08, 2009.

Sun, C. L., Brauer, S. L., Cadillo-Quiroz, H., Zinder, S. H., and Yavitt, J. B.: Seasonal changes in methanogenesis and methanogenic community in three peat- 
lands, New York State, Front. Microbiol., 3, 1-8, https://doi.org/10.3389/fmicb.2012.00081, 2012.

Takai, K. and Horikoshi, K.: Rapid detection and quantification of members of the archaeal community by quantitative PCR using fluorogenic probes, Appl. Environ. Microb., 66, 5066-5072, 2000.

Tuittila, E.-S., Komulainen, V. M., Vasander, H., Nykänen, H., Martikainen, P. J., and Laine, J.: Methane dynamics of a restored cut-away peatland, Global Change Biol., 6, 569-581, https://doi.org/10.1046/j.1365-2486.2000.00341.x, 2000.

Urbanová, Z., Picek, T., and Bárta, J.: Effect of re-wetting on carbon and nutrient fluxes, greenhouse gas production, and diversity of methanogenic archaeal community, Ecol. Eng., 37, 1017-1026, https://doi.org/10.1016/j.ecoleng.2010.07.012, 2011.

Urbanová, Z., Bárta, J., and Picek, T.: Methane emissions and methanogenic archaea on pristine, drained and restored mountain peatlands, central Europe, Ecosystems, 16, 664-677, https://doi.org/10.1007/s10021-013-9637-4, 2013.

van Bodegom, P., Stams, F., Mollema, L., Boeke, S., and Leffelaar, P.: Methane oxidation and the competition for oxygen in the rice rhizosphere, Appl. Environ. Microb., 67, 3586-3597, https://doi.org/10.1128/AEM.67.8.3586-3597.2001, 2001.

Vanselow-Algan, M., Schmidt, S. R., Greven, M., Fiencke, C., Kutzbach, L., and Pfeiffer, E.-M.: High methane emissions dominated annual greenhouse gas balances 30 years after bog rewetting, Biogeosciences, 12, 4361-4371, https://doi.org/10.5194/bg-12-4361-2015, 2015.

Voigtländer, U., Schmidt, J., and Scheller, W.: Pflege-und Entwicklungsplan NSG Heiligensee und Hütelmoor, 1996.

Wagner, D.: Effect of varying soil water potentials on methanogenesis in aerated marshland soils, Sci. Rep.-UK, 7, 14706, https://doi.org/10.1038/s41598-017-14980-y, 2017.

Weisner, E. and Schernewski, G.: Adaptation to climate change: a combined coastal protection and re-alignment scheme in a Baltic tourism region, J. Coast. Res., 65, 1963-1968, https://doi.org/10.2112/SI65-332.1, 2013.

Wen, X., Yang, S., Horn, F., Winkel, M., Wagner, D., and Liebner, S.: Global biogeographic analysis of methanogenic archaea identifies community-shaping factors of natural environments, Frontiers in Microbiology, 8, 1-13, https://doi.org/10.3389/fmicb.2017.01339, 2017.
Wickham, H.: ggplot2: Elegant Graphics for Data Analysis, Springer, New York, 2009.

Wilhelm, E., Batino, R., and Wilcock, R. J.: Low-pressure solubility of gases in liquid water, Chem. Rev., 77, 219-262, https://doi.org/10.1021/cr60306a003, 1977.

Wilson, D., Blain, D., Couwenburg, J., Evans, C. D., Murdiyarso, D., Page, S. E., Renou-Wilson, F., Rieley, J. O., Sirin, A., Strack, M., and Tuittila, E.-S.: Greenhouse gas emission factors associated with rewetting of organic soils, Mires Peat, 17, 1-28, https://doi.org/10.19189/MaP.2016.OMB.222, 2016.

Winkel, M., Mitzscherling, J., Overduin, P. P., Horn, F., Winterfeld, M., Rijkers, R., Grigoriev, M. N., Knoblauch, C., Mangelsdorf, K., Wagner, D., and Liebner, S.: Anaerobic methanotrophic communities thrive in deep submarine permafrost, Sci. Rep.-UK, 8, 1-13, https://doi.org/10.1038/s41598-018-19505-9, 2018.

Yrjälä, K., Tuomivirta, T. T., Juottonen, H., Putkinen, A., Lappi, K., Tuittila, E.-S., Penttila, T., Minkkinen, K., Laines, J., Peltoniemi, K., and Fritze, H.: $\mathrm{CH}_{4}$ production and oxidation processes in a boreal fen ecosystem after long-term water table drawdown, Global Change Biol., 17, 1311-1320, https://doi.org/10.1111/j.1365-2486.2010.02290.x, 2011.

Zak, D. and Gelbrecht, J.: The mobilisation of phosphorus, organic carbon, and ammonium in the initial stage of fen rewetting (a case study from NE Germany), Biogeochemistry, 85, 141-151, https://doi.org/10.1007/s10533-007-9122-2, 2007.

Zak, D., Reuter, H., Augustin, J., Shatwell, T., Barth, M., Gelbrecht, J., and McInnes, R. J.: Changes of the $\mathrm{CO}_{2}$ and $\mathrm{CH}_{4}$ production potential of rewetted fens in the perspective of temporal vegetation shifts, Biogeosciences, 12, 2455-2468, https://doi.org/10.5194/bg-12-2455-2015, 2015.

Zhang, J., Kobert, K., Flouri, T., and Stamatakis, A.: PEAR: a fast and accurate Illumina Paired-End reAd merger, Bioinformatics, 30, 614-620, https://doi.org/10.1093/bioinformatics/btt593, 2014.

Zhou, X., Zhang, Z., Tian, L., Li, X., and Tian, C.: Microbial communities in peatlands along a chronosequence on the Sanjiang Plain, China, Nature Scientific Reports, 7, 1-11, https://doi.org/10.1038/s41598-017-10436-5, 2017. 